The

Carl Beck Papers

in Russian \&

East European Studies

Number 1304

Susan Zayer Rupp

The Struggle in the East: Opposition Politics in Siberia, 1918 
Susan Zayer Rupp is an assistant professor of history at Wake Forest University. Her work on the Civil War in the East has also appeared in "The Russian Review" vol. 56 no. 2 (April 1997). Professor Rupp is currently working on a study of lawyers in the late imperial period.

No. 1304, August 1998

C 1998 by The Center for Russian and East European Studies, a program of the University Center for International Studies, University of Pittsburgh

ISSN 0889-275X

The Carl Beck Papers

Editors: William Chase, Bob Donnorummo, Ronald H. Linden

Managing Editor: Eileen L. O'Malley

Cover design: Mike Savitski

Submissions to The Carl Beck Papers are welcome. Manuscripts must be in English, doublespaced throughout, and less than 120 pages in length. Acceptance is based on anonymous review. Mail submissions to: Editor, The Carl Beck Papers, Center for Russian and East European Studies, 4G-17 Forbes Quadrangle, University of Pittsburgh, Pittsburgh, PA 15260. 


\section{The Struggle in the East: Opposition Politics in Siberia, 1918}

In comparison with the events of 1917, the Russian Civil War has been little studied, resulting in a problematic historiography that depicts the war as a struggle between Reds and Whites, with the opposition to the Bolsheviks reduced to reactionary officers and restorationist political forces. Soviet historians long made a virtual industry out of studying the civil war, but their work was most often distorted by the constraints of Marxist theory and party orthodoxy. Most Western studies of the political opposition focus on a single party and are often limited to the period prior to the outbreak of the civil war. ${ }^{1}$ Over the last decade, dramatic political changes in the former Soviet Union, accompanied by the opening of previously inaccessible archives, have spurred renewed interest in the revolutionary period and the various political groups active during that time. This examination of the opposition in Siberia prior to the Kolchak coup in November 1918 addresses a seldom explored chapter of the civil war and reveals the divisions among the forces of the political center, particularly the fracture between moderate socialists and erstwhile liberals, which fatally undermined the viability of a democratic alternative to the Bolshevik regime.

While mirroring many of the political developments that took place in Russia as a whole, the Siberian experience differs in that the potential appeal of the Bolsheviks was significantly less than was the case in European Russia. With a small working class and a peasantry that did not suffer from the land hunger of the central territories, Siberia's population evinced little enthusiasm for the Bolsheviks in 1917. Thus, it would seem logical that moderate political forces, particularly the Socialist Revolutionaries, would have a substantial chance of success in this region. And yet, as in European Russia, centrist political forces failed to mount an effective challenge to the Bolsheviks, instead giving way to a military dictatorship by the end of 1918. Moderate Regionalists and Socialist Revolutionaries organized 
both military forces and a civil administration in opposition to Bolshevik rule, but their accomplishments were undone by conflict and division engendered over the course of 1917-1918.

The Regionalists, who did not enjoy significant popular support prior to 1917, became increasingly alienated from the socialists and moved toward the embrace of rightist officers and trade-industrial circles in Siberia. The Socialist Revolutionaries did have popular support, but were unable to transform this into an effective mandate and adopted an ill-fated policy of cooperation with those to their right. Democratic forces in Siberia, shaken by the experience of 1917 and facing an essentially apolitical peasant populace, were quickly displaced by the Whites. This short-lived chapter of the civil war sheds light on both the politics of the revolutionary period and the broader nature of Russian political culture, which seemed incapable of supporting moderate, democratic rule.

\section{Siberian Regionalism and Revolutionary Politics}

In order to better assess the nature of the opposition in Siberia, we must briefly consider political developments in the region prior to the outbreak of the civil war. Although quickly bypassed by events in 1917 and thereafter, the Regionalists were involved in significant organizational work in Siberia early in the revolutionary period, and they continued to present an alternative to the Bolsheviks distinct from that offered by either the Socialist Revolutionaries or the increasingly conservative Kadets (Constitutional Democratic Party).

Siberian Regionalism, like Russian Populism, first developed among university students during the Great Reform era of the 1860s. The founders and chief theorists of the Regionalist movement, G. N. Potanin and N. M. Iadrintsev, concentrated their efforts on inculcating a sense of Siberian patriotism dedicated to the future "civic development" of the region by means of economic growth, the 
introduction of self-administration (particularly the zemstvo and an open court system), and education. ${ }^{2}$ Regionalists believed that the realization of their program would take time and depended upon the gradual winning over of public opinion. In a letter of 1873 to Iadrintsev, Potanin despaired of the fact that "in Siberian cities there is no social life, there are no people who love their rodina (motherland). ${ }^{13}$ As gradualists, the Regionalists supported the idea of Siberian autonomy rather than independence, and while they continued to present themselves as socialists they advocated an essentially liberal democratic agenda. ${ }^{4}$

The declaration of the rights of free speech and assembly following the February Revolution provided Regionalists with new opportunities to promote their program. The movement had little funding, however, and, as had been the case during the Revolution of 1905, Regionalists found it difficult to compete with the national political parties, particularly those on the left. The Regionalist program itself shifted noticeably leftward in the months following the February Revolution, as socialists in Siberia combined Regionalist demands with their more radical social and economic agenda. The Socialist Revolutionary Party, despite persistent internal differences and organizational shortcomings, grew rapidly in Siberia after February, with 251 active party organizations in $1917 .^{5}$

A series of conferences, culminating in the convening of the Siberian Regional Duma in January 1918, revealed the differences among the political forces in Siberia, along with a more general radicalization. Although Regionalists actively participated in these various assemblies, their influence was clearly secondary to that of the Socialist Revolutionaries. The coalitionist Provincial Executive Committee in Tomsk, the acting government in the province after February, first resolved to convene a regional congress in order to address the possibilities for greater economic coordination in Siberia in the face of growing shortages. It is unclear whether the delegates who assembled in August were elected or simply chosen by the committee itself. Forty-eight of the seventy-two participants were socialists, and professionals and sluzhashchie (white-collar workers) clearly predominated. Given the limited attendance, the delegates declared the assembly 
to be a preliminary to the forthcoming regional congress, and they dispersed just one week after convening. As V. Vegman, one of the early Soviet historians of the civil war in Siberia, caustically remarked, "By the first day, everyone recognized that this wasn't a congress but confusion. "6 The Siberian populace evinced little interest in this assembly or those that were convened in the months to come.

The opening of the regional congress on 8 October was attended by more than twice the number of delegates as had met two months earlier. ${ }^{7}$ Discussions focused on the division of powers in a future federated republic; Siberia was to possess full legislative, executive, and judicial autonomy save for foreign policy, military matters, and federal taxation. ${ }^{8}$ The centerpiece of the new government in Siberia, declared the regional congress, was to be a democratically elected regional duma to which a council of ministers would be responsible. This plan for administrative autonomy represented the fulfillment of the primary desideratum of the Regionalists. The leftism of the congress delegates is shown in resolutions on a number of issues. On the land question, for example, they asserted that "private ownership of land in Siberia must not exist in the future." 9 This amalgam of elements of the Regionalist agenda and the more radical demands of the Socialist Revolutionaries temporarily concealed growing divisions among political parties in Siberia.

An Executive Committee chosen by the regional congress convened an Extraordinary Regional Congress in mid-December in response to the October Revolution and the progressive spread of Bolshevik power in Siberia. The 155 members of this congress, delegated by a variety of public and cooperative organizations, declared that until the convening of the Constituent Assembly all authority in Siberia was to be invested in the soon to be elected Regional Duma; a Provisional Regional Council chosen by the congress was established to secure the convening of the Regional Duma. ${ }^{10}$ The Socialist Revolutionary majority at the December assembly excluded propertied elements from voting in the upcoming elections to the Regional Duma, which were to be open to party candidates from the Popular Socialists on the right to the Bolsheviks on the left." This stance 
accorded with the position adopted by Siberia's Socialist Revolutionaries as far back as April, when a regional conference of party members in Western Siberia asserted that "tactical agreements and blocs between socialist groups are necessary and desirable, " but rejected any cooperation with the so-called bourgeois parties. ${ }^{12}$ As will be discussed below, the Socialist Revolutionaries' stance on cooperation with the right was not definitively settled and would fluctuate considerably over the course of the coming year. The franchise provisions adopted in December, along with the fact that a significant number of delegates to the extraordinary congress were representatives of the soviets, later provided ammunition to those on the right, who accused the Socialist Revolutionaries of acting in concert with the Bolsheviks. ${ }^{13}$ The leftism of the extraordinary congress, or in any case the perception of it, led to Potanin's resignation from the Provisional Regional Council-a signal of the Regionalists' increasing alienation from the socialists.

Socialist dominance of the December congress is reflected in the radical tenor of many resolutions, including that regarding the soviets: "The soviets bring consciousness, clarity, light, and expediency to the movement and life of the laborers. The soviets are not only the mind of labor democracy, they are also the guards, the sentries to protect all the victories of the popular-labor revolution. "14 While the Socialist Revolutionaries supported the soviets, a gathering of party members in Novonikolaevsk just one month after the meeting of the extraordinary congress described the Constituent Assembly as the sole legitimate representative body in Russia, with the soviets conceived of as strictly executive bodies. Party members in Tomsk portrayed the soviets as a "transitional step to the Constituent Assembly, no more."15

Despite differences between socialists and Regionalists, the delegates were unanimous in condemning the Bolshevik seizure of power and in calling for the creation of volunteer forces to defend the recently dispersed Constituent Assembly against the newly established regime. A. A. Krakovetskii, who had commanded the Irkutsk garrison and had been elected to the Constituent Assembly as a representative of troops in the Romanian theater, was dispatched to Kiev to raise 
a force from among Siberian units stationed on the front. ${ }^{16}$ Moreover, in late December, the Socialist Revolutionaries P. Ia. Derber and E. V. Zakharov, members of the Provisional Regional Council appointed by the extraordinary congress, met with Major Jules Pichon (a member of the French military mission in Petrograd who had been sent to gather intelligence in Siberia), but failed to secure any promise of support. ${ }^{17}$ These actions reflect a determined if as yet ineffective opposition to Bolshevik rule and show the forces of opposition presenting themselves as the government in Siberia even prior to the convening of the Regional Duma. The Provisional Regional Council's primary responsibility was to secure the convening of this assembly, but there was some sense that the council would act as an interim cabinet as well. Jonathan Smele writes that it "might properly be regarded as the first Siberian government of the civil war." 18

\section{The Opposition Gathers Its Forces}

On 21 January 1918, the Regional Duma opened in Tomsk with ninetythree delegates in attendance, fifty-six of whom were Socialist Revolutionaries (another five were Mensheviks). ${ }^{19}$ Proclaiming the slogan of "through an autonomous Siberia to the rebirth of a free Russia," the duma also laid claim to the legacy of the February Revolution and upheld the authority of the Constituent Assembly. ${ }^{20}$ The delegates approved the Constituent Assembly's decree on land and called for the nationalization of mining industries and banks. ${ }^{21}$ The duma repeated the call made a month earlier for the creation of a volunteer army to defend both the Constituent Assembly and Siberian autonomy. The Soviet historian S. G. Livshits condescendingly described the Regional Duma as an "ersatz Siberian Uchredilka (Constituent Assembly), to which the Socialist Revolutionaries intended to 'delegate' authority. "22 Certainly, there were significant similarities between the Regional Duma's program and that of the Socialist Revolutionary Party, and as a 
result it is not surprising that nonsocialists would have little sympathy for either the Regional Duma or its program. In remarking on the resolutions adopted by the duma, G. K. Guins, a conservative who later became state secretary of the opposition government in Siberia, wrote: "this is not a real program, but only a political game in competition with the Bolsheviks. ${ }^{23}$ The divisions that had emerged over the course of 1917 had survived into the new year, and the forces of opposition in Siberia were united only by their hatred of the Bolsheviks.

The position of the Bolsheviks in Siberia in early 1918 was far from secure. Throughout much of 1917, most Social Democrats in Siberia supported a moderate policy line and were sympathetic toward the idea of party reunification. Less than half of Siberian uezdy (districts) had any sort of Bolshevik party presence, and there were only twelve thousand Bolsheviks in all of Siberia. ${ }^{24}$ The All-Siberian Congress of Soviets, meeting in Irkutsk in mid-October 1917, included sixty-four Bolsheviks, eleven Mensheviks, fifty Socialist Revolutionaries, and thirty-five Left Socialist Revolutionaries; while Bolshevik strength in Siberia had increased markedly by year's end, their representation at the congress was roughly equivalent to that of the moderate socialists. The Central Executive Committee elected by the congress, which came to be called Tsentrosibir', proclaimed its authority in Siberia soon after the October Revolution.

The Tomsk Soviet, which had declared its authority only in early December, was concerned about popular unrest caused by growing food shortages in the region and therefore hesitated to take action against the Regional Duma. It did so only on the orders of Tsentrosibir', which sent a representative to Tomsk to insure that its orders were carried out. Red Guard units closed the Regional Duma and arrested roughly a dozen delegates; the majority were simply escorted out of the city and warned not to return, an indication that the Bolsheviks did not perceive the Regional Duma as particularly threatening. ${ }^{25}$ A number of those delegates remaining at liberty met secretly at the Socialist Revolutionaries' provincial headquarters and a local consumer society in order to decide upon their future course of action. ${ }^{26}$ The last of these meetings was held on the night of 28 
January, at which time some twenty delegates chose a provisional government, headed by Derber, to administer Siberia until both the Regional Duma and the Constituent Assembly could be reconvened. The legitimacy of this government, chosen by the remnants of a hastily and indirectly elected body, was extremely uncertain. Moreover, only six of the twenty cabinet ministers appointed by the duma were present at these clandestine meetings. ${ }^{27}$ Fearing further Bolshevik reprisals, the delegates dispersed, with many fleeing to the safe haven of the Russian Far East.

Derber, along with most of the other Socialist Revolutionary cabinet appointees, went to Harbin and took up residence in a railroad car provided by General D. L. Khorvat, the director of the Chinese-Eastern Railway. ${ }^{28}$ Several members of this peripatetic group later relocated to Vladivostok just prior to its liberation by the Czech Legion, and on 29 June, with the backing of the city duma and the regional zemstvo, declared themselves the Provisional Government of Autonomous Siberia. This ephemeral government, located in distant Vladivostok and lacking any financial and administrative resources, unsuccessfully sought to assert its authority over a rival government established in Omsk, which was based upon those cabinet appointees (most of whom were nonsocialists) who had remained in Western Siberia after the dispersal of the Regional Duma. ${ }^{29}$

Before dispersing, the delegates to the Regional Duma had created the West Siberian Commissariat as a temporary body responsible for organizing an armed force to overthrow the Bolsheviks. Over the next four months, the commissariat established underground units totaling some 6,500 to 7,000 men; Siberia's cooperatives provided much of the funding for these forces. Zakupsbyt (the Union of Siberian Co-operative Unions), established in 1916, was an important backer of the West Siberian commissariat, as were the butter, consumer, and credit cooperatives. A January 1918 congress of cooperatives, at which seventy-five of the eighty-eight delegates were members of the Socialist Revolutionary Party, promised a series of loans to the Regional Duma. Although the promised amounts 
were never provided in full, some two hundred thousand rubles were given to the West Siberian Commissariat prior to the overthrow of the Bolsheviks. ${ }^{30}$

A. N. Grishin-Almazov, who had worked for Zakupsbyt before joining the underground in Novonikolaevsk, traveled throughout Western Siberia with P. Ia. Mikhailov, overseeing the creation of these opposition units. Whereas Mikhailov was a Socialist Revolutionary,Grishin-Almazov's political fealties, like those of many who became involved in the military underground, were far less certain. At one time, he had been a Socialist Revolutionary, but he left the party after the overthrow of the Bolsheviks in an effort to win over the officer corps, the majority of whom were hostile toward the socialists. ${ }^{31}$

Paul Dotsenko, a Socialist Revolutionary active in the Siberian opposition movement, maintains that those involved in the military underground were supposed to recognize the authority of both the Constituent Assembly and the Regional Duma and accept the principle of a democratic army..$^{32}$ Those who joined were bound together by their hatred of the Bolsheviks, yet were divided by political allegiances. For example, one young officer in Irkutsk described his refusal to cooperate with the Socialist Revolutionaries, ${ }^{33}$ and three separate military organizations were created in Tomsk: a Socialist Revolutionary unit of eight to nine hundred men, another unit of nine hundred to a thousand officers who refused to work with the Socialist Revolutionaries, and a third group of approximately one hundred who supported the restoration of tsarist rule. The largest single military force in Western Siberia consisted of two thousand troops in Omsk led by P. P. Ivanov-Rinov, the commander of the Steppe Siberian Cossack Corps. The Cossacks in Siberia were concerned above all else with the preservation of their autonomy, and their political attitudes were highly suspect from the perspective of the Socialist Revolutionaries. Mel'gunov writes that "it would be a serious mistake to think that some sort of orthodox thinking, socialist-populists joined the SR military organization. No, those who joined did so in a search for 'any point of support.' The SRs, or more accurately the 'firm' of the Siberian Government, provided that point of support, particularly given the passivity of other political groups. ${ }^{134}$ 
Officers dispatched by General M. V. Alekseev, the commander of the Volunteer Army in the south, on observing the fragmentation of the military underground in Siberia in the spring of 1918, reported that "up to the time of the Czechoslovak revolt in May 1918, the situation in Siberia was such that it did not give reason to hope for the possibility of overthrowing Soviet power without help from outside. " 35 They argued that the socialist-dominated units were of little military value, while the Cossacks displayed "a certain moral dissoluteness . . . a tendency to be ruled more by the egotistical motives of their atamans than by a recognition of civic duty. ${ }^{136}$ In his report to the French ambassador in Peking, Major Pichon similarly advised against supporting the opposition forces because of serious internal divisions. ${ }^{37}$

Representatives of underground military units from Barnaul, Tomsk, and Novonikolaevsk met on 3 February, and several additional units (including the Siberian Cossacks) gathered on 3 May under Grishin-Almazov's leadership. ${ }^{38}$ An uprising by the opposition forces, to occur simultaneously in several cities, was planned for 10 June but was preempted by the outbreak of the revolt of the Czech Legion in late May. This force of approximately forty thousand Czechs and Slovaks, assembled in 1917 from troops held in Russian prisoner-of-war camps, was subordinated to the Czechoslovak National Council and French military command. Designed to strengthen claims for Czechoslovak national independence after the war, the legion's troops in Russia found themselves in a very uneasy situation after the October Revolution and Bolshevik withdrawal from the war. In March 1918, representatives of the Czechoslovak National Council in Russia and the Bolshevik authorities in Moscow agreed to the transport of the legion to Vladivostok for eventual redeployment on the Western front. The terms of this agreement allowed the troops to retain some weapons for defensive purposes, but Bolshevik authorities along the railroad lines often insisted upon complete disarmament; the resulting confrontations culminated in a general revolt. ${ }^{39}$ Dispersed over thousands of miles of railroad track between Penza and Vladivostok, the legion's forces established contact with various opposition groups 
in the east and easily overwhelmed the less capable Bolshevik forces in one city and town after another. The forces of the West Siberian Commissariat led aborted revolts in Tomsk, Barnaul, and Irkutsk, while they were successful in Krasnoyarsk, Biisk, Semipalatinsk, and Omsk; these victories may in part be attributed to the Bolsheviks' panicked flight from the advancing legion.

With the overthrow of the Bolsheviks in Tomsk on 1 June, the West Siberian Commissariat announced that the "yoke of the new autocracy is destroyed"40 and declared authority over the newly liberated territories despite the fact that the commissariat had been created solely to organize military forces against the Bolsheviks. The new government was led by P. Ia. Mikhailov, B. D. Markov, M. E. Lindberg, and L. Sidorov, all of whom were Socialist Revolutionaries. Markov, Mikhailov, and Lindberg had been delegates to the Constituent Assembly, but with the exception of Sidorov, who had been chairman of the Tomsk zemstvo after the February Revolution, they lacked governmental experience and chose to recruit individuals for the new administration on the basis of their technical qualifications and experience rather than political allegiance. ${ }^{41}$ Dotsenko later claimed, as did other Socialist Revolutionaries, that such an approach seriously compromised the commissariat. "The state apparatus thus came to be bogged down with technicians who, far from sharing the principles of democracy, were often downright hostile to the idea of democratic power. ${ }^{142}$ Yet a congress of Socialist Revolutionaries in Siberia held in late June insisted upon the necessity of a united (obshchenarodnyi) front, arguing that divisions among the democratic forces would be fatal to the struggle against the Bolsheviks. ${ }^{43}$ In a reversal of their earlier position rejecting cooperation with the bourgeoisie and excluding them from the Regional Duma, the Socialist Revolutionaries in Siberia now extended their hand to all opposition groups, but this attempt to overcome the divisions of 1917 only revived earlier suspicions and hostility. Guins, who was appointed state secretary in the new government, joined the Regionalist delegates to the Regional Duma in urging those individuals appointed to the cabinet in January who had remained in the area to declare their authority as quickly as 
possible and replace the purely Socialist Revolutionary West Siberian Commissariat.

While the West Siberian Commissariat pursued a coalition strategy in personnel matters, its policies conformed closely to the Socialist Revolutionary program. The commissariat described itself as a labor democracy and asserted that Soviet decrees would be retained if they "proved to be vital [zhiznennye]. "44 One of the commissariat's earliest decrees called for the denationalization of industry, but at the same time warned against precipitous, independent action in this matter. ${ }^{45}$ A later decree repeated the call for denationalization with the exception of cases where this might lead to the "cessation or decline of production in an enterprise of exceptional state importance. "46 In practice, such ambiguous wording allowed the commissariat to retain significant control over industry. A similarly mixed form of state and private control was established in the agricultural sphere with the creation of a Food Bureau (to include representatives of the cooperatives, chambers of commerce, the People's Bank, and the government) to oversee the production and distribution of basic foodstuffs. ${ }^{47}$

Local administration was temporarily entrusted to appointed commissars who were to serve only until zemstvos and city dumas could be reestablished. Representatives of the government were instructed "not to act against any social class or party organization as long as it did not evince opposition to the Provisional Siberian Government or try to obtain governmental rights for itself. ${ }^{148}$ The new authorities were cautious about exercising police powers and established investigative commissions, including representatives of the political parties and unions, that were to be notified within twenty-four hours of the detention of any suspects by the military. ${ }^{49}$ These decrees all indicate that the West Siberian Commissariat perceived of itself as a revolutionary government that would remain true to democratic principles and would be slow to employ repressive measures.

Although deferring to the authority of the Regional Duma which had created it, and to the cabinet the duma had appointed in late January, the commissariat was reluctant to surrender power to those individuals who had 
resurfaced in Omsk to claim their posts, only one of whom belonged to the Socialist Revolutionary Party. At the very last moment of negotiations on the transfer of power, on the evening of 30 June, the commissariat members hesitated; they disliked I. A. Mikhailov (minister of finance in the cabinet, not to be confused with the commissariat's Pavel Mikhailov) and were uncertain about the political reliability of several other ministers. The commissariat's suspicions were reciprocated, for when Sidorov asked about the particulars of the future government's program, I. A. Mikhailov angrily inquired whether this was simply a matter of curiosity or some sort of demand. The difficulties faced by the Socialist Revolutionaries in Siberia, who recognized the need to cooperate with those to their right in the struggle against the Bolsheviks while still maintaining their commitment to a revolutionary agenda, are evident.

Despite their reservations, the leaders of the West Siberian Commissariat did cede power to the newly assembled cabinet. Sidorov remarked that while the commissariat had done a good job in organizing the military underground and participating in the overthrow of the Bolsheviks, it experienced "some uncertainty" about its own authority, given its ill-defined status as a subordinate body invested with only limited and temporary powers. The members of the commissariat were also concerned about the absence of a functioning representative body in Siberia, since the Regional Duma had not yet been reconvened, as well as the probable hostility of trade and industry circles, problems that the new government might be better able to address than could the commissariat. ${ }^{50}$ The tensions accompanying the transfer of power testify to the persistence of divisions within the anti-Bolshevik opposition and uncertainties about the struggle to come. 


\section{The Opposition in Power}

The Provisional Siberian Government, as the newly reconstituted cabinet declared itself, was clearly more conservative than either the West Siberian Commissariat or the cabinet appointed in January. P. V. Vologodskii, who became prime minister of the government in Derber's absence, was a man of uncertain political loyalties. Although he had sympathized with the Populists as a student at St. Petersburg University (he was expelled in 1887 as a political "undesirable"), Vologodskii apparently never joined any party. ${ }^{\text {s1 }}$ While probably best described as a well-intentioned liberal, Vologodskii's political orientation had little impact on the new government. He had a nervous temperament, was at times prone to hysteria, and was easily manipulated by those around him. The weakness of Vologodskii's character is evident on virtually every page of his diary, as he repeatedly complains of exhaustion, headaches, and an assortment of other maladies. I. A. Mikhailov persuaded Vologodskii to accept the prime ministership in late June; Vologodskii remarked that "I did not protest against Mikhailov's suggestion at particular length or with particular energy. ${ }^{\text {52 }}$ The conservative minister of finance Mikhailov, along with state secretary Guins, exercised inordinate influence over both Vologodskii and the Provisional Siberian Government as a whole in the months to come. Without doubt, Mikhailov was the most manipulative and distrusted member of the government; even the crafty Guins describes him as "omnipresent and omniscient. ${ }^{153}$ With ties to rightist circles in Omsk, he quickly established himself as a central figure in Siberian politics despite his tender years..$^{54}$

Patushinskii, Krutovskii, and Shatilov were the most leftist of the ministers in Omsk. G. B. Patushinskii, appointed minister of justice, had made a name for himself as a defense lawyer for the Lena goldminers after the 1912 massacre; both friends and foes praised him as energetic and intelligent, while remarking upon his nervousness and short temper. ${ }^{55}$ Trained as a doctor, V. M. Krutovskii was named minister of health; he had been a Progressist delegate to the First Duma and had 
served as the provincial commissar in Enisei under the Provisional Government. ${ }^{56}$ One Soviet historian described Krutovskii as an "SR-leaning" (eserstvuiushchii) Regionalist, but of the three ministers only M. B. Shatilov, the minister of minority affairs, was a member of the Socialist Revolutionary Party. ${ }^{57}$ Krutovskii and Shatilov soon withdrew from governmental affairs due to growing uneasiness about the government's conservative complexion, thus leaving Patushinskii relatively isolated in the cabinet.

The contrast between the Provisional Siberian Government and the West Siberian Commissariat, with its rhetoric of revolutionary democracy, was clear from the very start. In its first official pronouncement, the new government appealed to the principle of gosudarstvennost' (state authority) and the reestablishment of law and order. The commissariat's departments were renamed ministries, and the collegial principle in the operation of local commissariats was abandoned. ${ }^{58}$ A decree of 4 July nullified all Soviet legislation, in contrast to the commissariat's case-by-case approach. ${ }^{59}$ The state monopoly and fixed prices on grain were abolished; land was to be returned to previous owners upon request, with the final disposition of this issue left to the Constituent Assembly. By midJuly, both the Ministry of Internal Affairs and military commanders were empowered to declare martial law, indicating the new government's greater readiness to employ its police powers. ${ }^{60}$ All these policies stand in sharp contrast to those of the West Siberian Commissariat and signify a general retreat from the revolutionary direction of developments in 1917.

In abandoning radical policies and rhetoric, the Provisional Siberian Government hoped to secure the support of the more conservative elements in Siberia. However, trade and industry circles regarded the government as a creature of the socialist Regional Duma and thus as an object of suspicion and distaste. In mid-July, a congress of trade and industry representatives from the Urals and Siberia excoriated the Provisional Government of 1917 in Petrograd as weak and indecisive and insisted on the need for a government that would stand above party and class interests. ${ }^{61}$ Repeated interruptions of Patushinskii's speech to the congress 
demonstrate the delegates' antipathy toward the left, which they blamed for the catastrophic outcome of $1917 . .^{2}$ While recognizing the new Siberian government, the delegates insisted that no additional (i.e., leftist) ministers be included in the cabinet in order to prevent what they described as "harmful confusion in the minds of the population. ${ }^{63}$ The congress declined the invitation to elect representatives to the Regional Duma, and a further resolution cautioned against government responsibility to any representative assembly. Congress resolutions on economic matters, with demands for the complete denationalization of land and industry and a return to prerevolutionary practices in factory management, went significantly beyond those policies adopted by the government. ${ }^{64}$ Finally, the delegates called for the organization of their class independently of both the Regional Duma and the government, proposing the creation of trade-industrial chambers that could promote the group's interests in the formulation of future government policies. In the past, it was asserted, trade-industrial circles had been the passive victims of socialist experimentation; now it was necessary to gather their forces because "this class-the fundamental builder of state life, may again be prevented by the force of harmful political tendencies from fulfilling the duty that lies upon it and forced to remain in the position of a helpless observer of ongoing events. " resolution was a battle cry on the part of the propertied elements, who felt they had been neglected and abused over the course of the preceding year.

The Kadets sought to provide a political voice for these conservative sentiments. Because the Regionalist movement tended to siphon off the support of groups that traditionally had supported the Kadets in European Russia, the party had an insignificant presence in Siberia, with only some two hundred and fifty to four hundred members during the 1905 Revolution and few more in $1917 .{ }^{66}$ However, the influence of the Kadets grew over the course of 1918 as a result of heightened fears of socialism on the part of propertied elements as well as an influx of refugees from European Russia who supported the Kadet Party. With the overthrow of the Bolsheviks, V. A. Zhardetskii, the rightist leader of the Siberian Kadets, called for a one-man dictatorship while evoking the experience of 1917 : 
"the time of myths and illusions is over . . . It is essential that a strong, one-man dictatorship be introduced . . . Authority must not be under the control of any sort of deputies. No barristers of the Kerensky type, no literati of the Chernov type should be in power. ${ }^{167}$ Like the delegates to the trade-industrial congress, Zhardetskii and the Kadets rejected government responsibility to a representative assembly, stating "they should be responsible before their conscience, reason and history, and not to anyone else. ${ }^{168} \mathrm{He}$ went on to describe the Provisional Siberian Government as an alien, socialist body and yet argued for recognition of its authority-at least for the time being. While they offered their support to the new government, the Kadets "refused to regard the Siberian Regional Duma as expressing the opinions of the Siberian population and did not recognize its legislative rights" and warned of the threat from "those elements which make their goal the restoration of the governmental order of the February period. ${ }^{69}$ In the wake of the October Revolution, the Kadets had largely abandoned their traditional commitment to representative government. They did not participate in local or central government in Siberia until after the Kolchak coup, refusing to cooperate with the Socialist Revolutionaries or even those centrists who came to dominate the Provisional Siberian Government.

The Siberian army also presented a powerful force on the right, because most of the officers participating in the opposition distrusted both the West Siberian Commissariat and the government that succeeded it. ${ }^{70}$ Hostility between the army and the government led to conflict, displayed most clearly when Grishin-Almazov, the commander-in-chief and minister of war, was forced to resign after an embarrassing incident at a banquet in Ekaterinburg in early September, where he asserted in the presence of the Allied consuls that the Entente powers needed Russia more than the Russians needed them. The consuls immediately issued a joint statement calling for Grishin-Almazov's resignation, although the American consul general in Siberia, Ernest Lloyd Harris, maintained that "we simply called the attention of the Department of Foreign Affairs to the statements made and there let the matter rest. "71 
General A. I. Denikin asserts that Vologodskii and the Socialist Revolutionaries used this incident to rid themselves of a potential Bonaparte. Guins argues that the left disliked Grishin-Almazov and applauded his ouster; he maintains that the conflict was engineered by $M$. P. Golovachev, the young minister of foreign affairs described by Guins as a Germanophile who resented Grishin-Almazov's pro-Entente stance: ${ }^{n}$ Vologodskii substantiates at least a part of Guins's account in that on 4 September, Golovachev urged him that "for the satisfaction of the offended pride of the Allies . . . it was necessary to react to Grishin-Almazov's actions in the most decisive manner, including his replacement as Minister of War." $" 73$

While it appears that Golovachev was eager to be rid of Grishin-Almazov, there is no indication that the latter had much sympathy toward the Entente (his comments at the banquet seem to contradict this) nor that Golovachev acted out of any sympathy toward the Germans. What is clear, however, is that the government was divided over Grishin-Almazov's ouster, which was agreed to only after Vologodskii threatened to resign himself. The following night, Guins and I. A. Mikhailov met with Grishin-Almazov and raised the possibility of an armed coup; uncertain about the support of the army, Grishin-Almazov declined their offer. ${ }^{74}$ Grishin-Almazov's resignation did little to improve the relationship between the government and the army, as his successor, Ivanov-Rinov, commander of the Siberian Cossacks, was even further to the right than Grishin-Almazov had been. ${ }^{75}$ For example, Ivanov-Rinov quickly moved to restore elements of the traditional order in the army, including the highly symbolic reintroduction of epaulets. Dotsenko states that "once Grishin-Almazov had been discharged and Ivanov-Rinov had replaced him, an era of complete irresponsibility on the part of the military authorities began. "76 The ouster of Grishin-Almazov reflects the government's difficulty in controlling its own military, as well as providing a good sense of machinations taking place within the government itself.

While the Provisional Siberian Government failed to secure the support of those on the right, its policies alienated the popular classes, particularly workers. 
The government's stance toward labor was demonstrated as early as 21 June, even before the formal assumption of power, when Guins notified the Tomsk provincial commissariat that workers' control was to be replaced by state control in all enterprises. ${ }^{n}$ A decree of 6 July abolished the soviets and prohibited any form of political organization by workers. Provisions regarding the right to strike, the eight-hour workday, and the minimum wage were narrowed, and piece-rate wages were reintroduced. Vologodskii, in a speech in August, upheld notions of "free competition, healthy social policy, and good finances." He was highly critical of union interference in factory management, insisted on an end to workers' control, and warned that the workers' movement "sometimes takes on the form of unacceptable excesses." At the same time, he spoke favorably of more limited organizations such as labor exchanges, conciliation boards, and mutual aid societies. Workers' organizations were to be given complete freedom, but only "within the framework of the clearly defined interests of the workers' economic and cultural well-being." 78 Apparently, the government was to determine which activities and organizations met or exceeded these limits.

Vologodskii's cautionary message reflected the Provisional Siberian Government's determination to reverse many of the gains made by labor in the preceding year and was certain to encourage worker suspicion if not outright hostility. Empowered by developments in 1917, even if only rhetorically, workers would quickly react against a government that attempted to rescind concessions so recently won. Union conferences held in June and July passed resolutions offering conditional support to the newly established government, but when workers came to believe that the authorities were undermining the principle of narodovlastie (popular sovereignty) and the gains made by labor, their support dissipated. Sixteen strikes occurred in July and August, most of them among the radical miners of the Kuznets Basin. ${ }^{79}$ A general strike of workers in Novonikolaevsk took place in August, and isolated railroad workers' strikes culminated in a general strike of the industry in October. Military suppression of strike actions only further alienated Siberia's workers. 
One could argue, however, that the response of the small Siberian working class was of less significance to the government than that of the vast peasant majority. Most Siberian peasants had larger landholdings than did peasants in central Russia, and therefore they were considerably less radical in 1917. Moreover, Bolshevik rule after October 1917, if experienced at all by Siberia's peasants, was often equated with the forcible confiscation of grain. The "Sovietization" of the Siberian countryside was not completed until the summer of 1918, and a significant number of villages had not encountered Bolshevik rule prior to the establishment of the opposition government. ${ }^{80}$ In a survey conducted by a newspaper just weeks before the overthrow of the Bolsheviks, more than a quarter of peasants failed to express any attitude toward the Soviet government; those opinions offered were frequently very general and ambivalent: "The village does not care who rules, just so there is justice," and "just so they give us plenty of land, and less taxes, and as to the parties, we can't see any difference. ${ }^{181}$

Peasant attitudes toward the Bolshevik regime were determined by considerations of personal loss or gain that rarely extended beyond the confines of the village. This fundamental perspective was little affected by the establishment of the Provisional Siberian Government. While of little practical import to the peasants of Siberia, where gentry landholding was virtually nonexistent, the opposition government's decree for the return of seized lands to their former owners was symbolic, indicating approbation of the prerevolutionary order. Moreover, a fundamental distrust of central authority, greatly encouraged by the disruptions of 1917, meant that efforts to collect taxes and enforce conscription, whatever the complexion of the government, would be seen by peasants as illegitimate. Reports from representatives of the Ministry of Internal Affairs of the Provisional Siberian Government in early August stated that seventeen of the thirtysix volosti (cantons) in Novonikolaevsk Province supported the government-most often conditionally; another thirteen were passive, while the remaining six could be considered hostile. ${ }^{82}$ 
Soviet historians most often described the isolated peasant disturbances in the summer and fall of 1918 as direct antecedents to the large-scale partisan movement that developed during the Kolchak period. ${ }^{83}$ This argument exaggerates the significance of early peasant unrest, which expressed opposition to particular policies rather than rejection of the government itself. For example, peasants in a district of Tobolsk Province took over a mobilization center in late August, released the conscripted villagers, and then returned to their homes. A week-long revolt in a district of Altai Province was also the result of opposition to mobilization, as well as government efforts to collect taxes. ${ }^{84}$ Such expressions of discontent were spontaneous and restricted to individual villages or districts, and it was only in the spring of 1919 that the peasants began to act with any significant organization or consistency against the Kolchak government, whose actions in the countryside were seen as both arbitrary and reactionary.

In an effort to bolster support among the populace, the Provisional Siberian Government reluctantly agreed to reconvene the Regional Duma. At a cabinet meeting of 6 July devoted to a discussion of this question, Guins argued for a fiveto six-month delay in order to prepare for new elections. Shatilov walked out of this meeting after arguing that Guins was exceeding the cabinet's authority by trying to place restrictions on a representative body to which the government itself was supposed to be responsible. ${ }^{85}$ Meanwhile, at an unofficial conference of delegates to the Regional Duma, the Regionalists endorsed the new government and the elderly Potanin vilified the Socialist Revolutionaries as a political force alien to Siberia.$^{86}$ Soon thereafter, a delegation from the Regional Duma led by the Socialist Revolutionary M. A. Krol' met with members of the cabinet in Omsk. The delegation urged the Provisional Siberian Government to join what it described as the forces of democracy and the people by relocating to Tomsk, the meeting place of the Regional Duma. While Krol' asserted that these meetings ended with expressions of mutual confidence between the government and the Regional Duma, he also confesses that he left Omsk with a heavy heart. ${ }^{87}$ The overthrow of the Bolsheviks had not led to a coalescing of the political forces that opposed them. 
Instead, divisions between the socialists and those to their right were becoming more pronounced, with signs of growing mistrust between the Socialist Revolutionary-dominated Regional Duma and the nonsocialist cabinet.

The entire cabinet attended the opening ceremonies of the reconvened Regional Duma on 15 August, with the exception of Grishin-Almazov, who arrived with a heavily armed contingent two or three days later. ${ }^{88}$ Approximately half of the ninety-seven delegates were Socialist Revolutionaries, another eight were Mensheviks. ${ }^{89}$ The number of Regionalist delegates is uncertain, with estimates ranging from four to twenty-eight. ${ }^{00}$ The Regionalists' position was strengthened considerably by the fact that most of the socialist cabinet appointees remained in the Russian Far East. Mel'gunov maintains that although they were in the minority, the Regionalists exercised a disproportionate influence because of their ties to the military. ${ }^{91}$ Although the Regionalists certainly would have been more likely to enjoy the sympathies of the army than would the Socialist Revolutionaries, there is no evidence to substantiate such a relationship. Krol' argues that the Regionalists promoted the idea of a military dictatorship and asserted that "only the socialist parties remained true to the idea of democracy, all the remaining liberal and even radical elements quickly veered to the right." ${ }^{22}$

While the nonsocialists in the Regional Duma had moved further toward the right, the Socialist Revolutionary delegates were at pains to present themselves as moderates who wanted to cooperate with the government in Omsk. In his address to the duma, E. E. Kolosov asserted that the Socialist Revolutionaries were "state-minded men" (gosudarstvenniki) and that those who claimed that the party was opposed to state authority were guilty of underhanded slander. As had been the case with the leaders of the West Siberian Commissariat, the Socialist Revolutionaries sought to overcome divisions within the opposition and called for self-restraint and legal activity within the confines of the duma. At the same time, Kolosov asserted that it should be understood that national and popular interests were coincident; he added: "we won't say that we're prepared to support the 
Provisional Government in everything, we won't assure anyone that we're happy with everything it does." 93

According to the terms of its understanding with the government, the Regional Duma was supposed to restrict itself to preparations for the inclusion of representatives of the propertied elements. ${ }^{94}$ Moreover, Prime Minister Vologodskii was slated to address the duma first, thereby asserting the primacy of the government in Omsk. Instead, several Constituent Assembly delegates, by mischance or machination, opened the first session with an appeal for closer ties with the Socialist Revolutionary government recently established in Samara. When Vologodskii finally got the chance to speak, he asserted that the government's authority emanated not only from the Regional Duma but "from existing circumstances and the unanimous recognition of the government by all circles of the population and social organizations. "95 The government thus claimed an authority independent of the Regional Duma; Vologodskii added that Siberia was not yet ready for a parliamentary form of government given prevailing "conditions of popular darkness, of complete illiteracy. ${ }^{196}$ The nonsocialists in Siberia evidently were disillusioned about the possibility of representative government, and under the pressure of increasing numbers of refugees from European Russia, they largely abandoned their earlier goals of regional autonomy as well.

A group of Socialist Revolutionary delegates, again led by Krol', attempted to bridge the growing gulf between the cabinet and the duma by inviting Vologodskii, along with the leftist ministers Patushinskii, Krutovskii, and Shatilov, to meet outside the confines of the official sessions. The delegates used this opportunity to express their misgivings about Grishin-Almazov, Golovachev, and I. A. Mikhailov. Their effort to win over the weak-willed prime minister and thus strengthen the left's position in the government apparently failed; Vologodskii remarked in his diary only that he left the meeting with "a heavy feeling. "97

In fact, in the weeks to follow, the government in Omsk became increasingly conservative. On 24 August, the Administrative Council was established, ostensibly a nonpartisan body whose purpose was the expediting of 
governmental business in the absence of a full cabinet. ${ }^{98}$ It is clear, however, that the council represented both a narrowing and a rightward shift of the government. After protesting Grishin-Almazov's removal, the council was invested with the authority to approve all cabinet appointments and dismissals. A later council decree expanded the application of the death penalty to cases of military desertion and insubordination, and transferred a wide range of criminal offenses to the jurisdiction of military tribunals. ${ }^{99}$ Finally, on 8 September the council claimed the authority, in the absence of a majority of cabinet members, to dissolve the Regional Duma if such was deemed necessary. ${ }^{100}$ Patushinskii resigned from the cabinet after refusing to sign this decree, although he had agreed to an act enlarging the competence of the Administrative Council only one day earlier. The signs of conflict between the increasingly conservative cabinet of the Provisional Siberian Government and the socialist-dominated representative assembly were obvious.

\section{The Contest for Power Among the Opposition Forces in the East}

Divisions within the opposition in Siberia were mirrored in the relationship between the Provisional Siberian Government in Omsk and its major competitor for power and authority in the liberated territories east of the Volga-the Komuch government, which derived both its name (a shortened form of Komitet chlenov Uchreditel'nogo Sobraniia) and its identity from the Constituent Assembly. From the time of its establishment in early June following the revolt of the Czech Legion, the government in Samara was dominated by the Socialist Revolutionaries, who had dispatched their representatives to the Volga region following the 8th Party Council in May. Like the West Siberian Commissariat, the Socialist Revolutionaries in Samara were uneasy about exercising power alone despite central party directives 
against cooperation with political forces to the right, and they appealed, with little success, to the other opposition parties for support. ${ }^{101}$

Komuch upheld the Socialist Revolutionary slogan of the "third path," in which the gains made by the laboring masses during 1917 would be preserved in the struggle against both the Bolsheviks and the forces of reaction. On its first day in power, the Komuch government issued a decree preserving all workers' organizations, including the often radical factory committees (fabzavkomy), and recognizing all collective labor agreements and protective legislation established under the Bolsheviks. The soviets were to be retained, although they were to serve as a political tribune for workers and a means of securing cooperation between labor and government rather than as organs of administration or economic management. A commission for the denationalization of industry was created, but the government retained control over all enterprises of vital state importance. Finally, the abolition of private property in land was reaffirmed, with provincial and district land committees to supervise redistribution. ${ }^{102}$ These policies bear a strong resemblance to those adopted by the West Siberian Commissariat and subsequently abandoned by the Provisional Siberian Government. The divergence between the opposition governments in Omsk and Samara-the tension between gosudarstvennost' and narodovlastie-thus replicated the division between the authorities in Omsk and the Regional Duma and provoked similar problems.

The military situation provided the earliest source of conflict between the two governments. The Komuch government, which at its height controlled the better part of five provinces along the Volga, had simultaneously to recruit and deploy its forces on the front, while the Provisional Siberian Government had the luxury of assembling its army safely in the rear. Moreover, ex-tsarist officers had little sympathy for the Komuch government and its democratically organized People's Army, and with the inducements of better pay and service far from the front, many were recruited into the Siberian army. A. I. Soloveichik, the secretary of the Samara Kadet party organization who later participated in both the Omsk and Kolchak governments, established an organization to recruit officers into the 
Siberian forces. ${ }^{103}$ The two governments also clashed over the liberated territories in the Urals. Komuch maintained that as the successor to the Constituent Assembly it should exercise authority over this region; the Provisional Siberian Government based its claims on longstanding economic ties between Siberia and the Urals and asserted that the latter preferred to be administered by Omsk.

Having balked at coordinating their activities in both civilian and military matters, the two governments had come to treat each other essentially as foreign powers. The representative from Omsk was barred from attending meetings of the Komuch government, while the Komuch representative to Siberia and its Department of Siberian Affairs (led by Markov, formerly of the West Siberian Commissariat) was associated with the Regional Duma rather than the government in Omsk. Given the uneasy relationship between the Provisional Siberian Government and the Regional Duma, the Komuch government's preference for working with the latter could not have been seen as anything other than a slap in the face by the authorities in Omsk. The two governments quickly came to an impasse.

The impetus for negotiations between the opposition governments in the east came from representatives of the Entente, the Czech Legion, and the coalitionist Union of Regeneration. Allied policy toward Russia fluctuated considerably over the course of the civil war, and there was little coordination among the Entente powers; however, all agreed that a unified opposition government was needed to mount an effective challenge to the Bolsheviks and to serve as a basis for Russia's future political order. The legion, having borne the brunt of the fighting in the east, was angry and frustrated that political squabbling prevented the Russian opposition from contributing more effectively to the military effort against the Bolsheviks. Although their political sympathies generally lay with the Socialist Revolutionaries, the legion's leaders were concerned primarily about the protection of their own troops, and to achieve this they supported the creation of a unified opposition government. 
The Union of Regeneration, established in the spring of 1918, was based upon individual membership rather than a coalition of parties. The leaders of the various parties represented in the Union, from the Socialist Revolutionaries on the left to the Kadets on the right, were either undecided about or hostile toward the idea of perpetuating a coalition that many believed had paved the way for the Bolshevik seizure of power. At the same time, there were those within these same parties who believed that the Bolsheviks could be defeated only by means of a coalition that would best represent the interests of the nation as a whole by standing above the sectarian politics that had crippled the forces for democracy in 1917. Several representatives of the Union who were dispatched to the east to publicize the group's program, including the Kadet L. A. Krol' and the Socialist Revolutionaries A. A. Argunov and V. E. Pavlov, also presented themselves as spokesmen for their parties, undoubtedly without the knowledge or consent of the explicitly nonpartisan Union. ${ }^{104}$ Other members of the Union, such as N. D. Avksent'ev and V. M. Zenzinov, who had come to the east as representatives of the Socialist Revolutionary Central Committee, acted instead as proponents of the Union's program and subsequently played a central role in the creation of a coalition government. ${ }^{105}$

The opposition forces in the east assembled in Cheliabinsk on 15-16 July. In describing the attitude of the Komuch and Provisional Siberian governments, Argunov wrote that "both sides came to the meeting with a feeling of enmity and distrust which did not leave them for a minute." 106 The delegates from Samara and Omsk were loath to meet at all, refusing to be photographed together and often limiting contacts to an exchange of notes between the railroad cars housing their delegations. At one point during the conference, a member of the Komuch government sent a note to Grishin-Almazov in which he tried to persuade the former Socialist Revolutionary to recognize Samara's authority. Grishin-Almazov responded that he rejected the appellation of "comrade" and dismissively added that "a dozen Socialist-Revolutionaries does not an All-Russian government make." 107 
The Komuch delegation tenaciously held to the position that all liberated territories should be subordinated to Samara, while allowing that other opposition governments in the east could exercise limited autonomy in accordance with the federal principle. ${ }^{108}$ The delegates from Omsk maintained that they represented the only legitimate government in Siberia and could not cede their authority to any other government; moreover, they disingenuously claimed that they were led to believe that the conference was intended only for an exchange of information and therefore they had not been empowered to conclude any binding agreements on behalf of their government. The chasm between the two governments was evident to all, despite the protestations of those like M. Ia. Gendel'man, a right-center member of the Socialist Revolutionary Central Committee and an advocate of coalition, who vainly asserted that those who "point to the irreconcilable relations that exist between the Siberian Government and the Committee [Komuch] in light of the differences in the positions of principles which they occupy" were mistaken. ${ }^{109}$

A second conference at Cheliabinsk, held 20-25 August, accomplished little more than the first. In fact, the participants could not even agree on the site of the coming All-Russian state conference. While the Komuch government, the Socialist Revolutionaries, and the Muslim representatives of the Bashkirs and Tatars argued that it should be held in Samara, the remaining delegations insisted that a "neutral" location like Cheliabinsk would be more appropriate. The presidium resolved the stalemate by choosing Ufa. ${ }^{110}$ This debate degenerated into a vitriolic exchange between Gendel'man and the conservative Kadet V. N. Pepeliaev, with the former alluding to the Kadets' ties to the Germans in the south and the latter making angry reference to the defeatist socialist Zimmerwald and Kienthal conferences. ${ }^{111}$ The events of the recent past colored the thinking of all those present at the conference, creating deepening fissures within the opposition.

A participant in the meetings at Cheliabinsk expressed little hope that the Ufa State Conference would be any more successful, stating that "one can assert with certainty that it too will end without results and may even lead to a formal 
break." 112 Despite the presence of forces in favor of compromise, the antipathies dividing the opposition were still very much in evidence at the opening of the conference on 8 September. While Avksent'ev addressed the gathering with a solemn reminder that the delegates were responsible for "saving our fatherland, "113 the Omsk delegation had not yet left for Ufa (and would only arrive four days later). Mikhailov explained to Avksent'ev that its departure had been delayed by a "serious political crisis." An exasperated Avksent'ev dismissed this apparent reference to the forced resignation of Grishin-Almazov as of little importance when compared to the mission of the conference-the creation of a united government for the overthrow of the Bolsheviks. ${ }^{114}$ Once they arrived in Ufa, the delegates from Omsk chose to remain in their official railroad car, further isolating themselves from the other conference participants who were staying at a city hotel. ${ }^{115}$

The Omsk government continued to express little willingness to cooperate with Komuch, and developments in the weeks since the conferences in Cheliabrisk could only have increased its reluctance. Just days before the conference opened at Ufa, Vologodskii left Omsk for negotiations with Entente representatives and opposition governments in the Russian Far East. The timing of this mission indicates that the Siberian government did not anticipate surrendering its authority in the near future. On 21 September the Provisional Government of Autonomous Siberia, headed by Derber and including several of the cabinet ministers appointed in late January, agreed to dissolve itself. A few days later General Khorvat agreed to recognize the authority of the Provisional Siberian Government in return for continued control of the Chinese-Eastern Railway Zone. Thus, rival claimants to authority in the Russian Far East, with the exception of the marauding bands of Ataman Semenov, had been effectively dealt with. Meetings with Entente representatives also produced generally favorable results, with promises of financial and military support from General Alfred Knox (head of the British military mission in Siberia) and E. L. G. Regnault (France's High Commissioner to Siberia). Only Roland Morris, the American ambassador to Japan who had been sent to assess the situation in Siberia, failed to offer much encouragement. ${ }^{116}$ In the 
meantime, Vologodskii instructed the delegation at Ufa not to rush into any agreement that might unfavorably affect the government's interests. I. I. Serebrennikov, who headed the Omsk delegation to Ufa, later wrote that the instructions given them at the time of their departure included the condition that Komuch should be completely subsumed by the newly created government and that "the Constituent Assembly of 1917 is to be quickly dissolved." If this condition was not met, the delegation might break off negotiations and withdraw from the conference altogether. ${ }^{117}$

Soviet historians generally described the Ufa State Conference in terms of a division between adherents of popular sovereignty and military dictatorship. In fact, as Avksent'ev later wrote in a letter to the Socialist Revolutionary Central Committee, what divided the delegates "wasn't the program of the government or its form, and not even the composition of the Directory, but the issue of the [1917] Constituent Assembly." 118 At the opening session of the conference, M. K. Vol'skii, a left-center member of the Socialist Revolutionary Central Committee and chairman of the Komuch government, argued that the only legitimate government in Russia would be one based upon popular sovereignty, which he defined as synonymous with the Constituent Assembly. This statement was met with "stormy and prolonged applause" from the various Muslim delegations, the Socialist Revolutionary and Menshevik parties, and the Congress of Cities and Zemstvos. ${ }^{119}$ V. V. Sapozhnikov, in presenting the Provisional Siberian Government's position at a later meeting of the negotiating commission, called for a government "responsible only before a future fully authoritative organ correctly expressing the popular will," thereby implicitly rejecting the already existing Constituent Assembly. ${ }^{120}$ His position was supported by the Cossack delegations, the Edinstvo Group, and the Kadet Party.

The positions toward the Constituent Assembly adopted by the various political parties represented at Ufa reflected in turn how each was affected by and interpreted the events of 1917. In the prerevolutionary period, the Constituent Assembly had been a central programmatic goal for all those political forces in 
Russia which had worked toward limiting the tsarist autocracy and securing the exercise of popular sovereignty. The attainment of this goal, however, ultimately proved empty, as the Bolsheviks had seized power by the time of the elections and dispersed the Constituent Assembly without encountering any significant resistance. For supporters of democracy in Russia, the complete collapse of such an essential symbol as the Constituent Assembly provoked a profound reappraisal of earlier beliefs. The Socialist Revolutionaries and the Mensheviks clung to their faith in the revolution and the masses in spite of the disappointments of 1917, while the Kadets and others on the right became distrustful of the masses and were disillusioned about the possibilities for democracy in Russia. By the end of 1918 the Constituent Assembly had taken on a new discursive reality, that of savior or pariah.

The compromise eventually reached at Ufa was the work of a negotiating commission, whose members readily agreed that the future Russian state should be a federated one and that a directory, as originally proposed by the Union of Regeneration in the summer of 1918 , would be the most appropriate form of government for the struggle against the Bolsheviks. There was also surprisingly little contention within the negotiating commission over programmatic issues with the sole exception of the land question, which from the early months of 1917 had taken on enormous symbolic significance in dividing Russia's political parties. ${ }^{121}$ In contrast, the question of the Constituent Assembly gave rise to protracted and bitter debate, with Gendel'man and Zenzinov, the Socialist Revolutionary members of the negotiating commission, opposed by the Kadet Krol' and the Omsk representatives, Sapozhnikov and Serebrennikov. At one point in the discussions, Serebrennikov reluctantly agreed that the Constituent Assembly should be allowed to convene, if only to prepare for new elections and then dissolve itself. When pressed by Gendel'man as to what the response would be if the assembly did not dissolve, Serebrennikov replied that "without deciding the question in advance, I would suggest that the Siberian government would retain freedom of action for itself." 122 This stance was consistent with the instructions sent by Vologodskii, which opposed the reconvening of the Socialist Revolutionary-dominated 
Constituent Assembly as elected in late 1917. The agreement signed at Ufa stated that the Constituent Assembly would be convened on 1 January 1919 with a quorum of 250 delegates, or on 1 February with 170 delegates. ${ }^{123}$

While agreeing to the creation of a directory government for the interim period, the delegates at Ufa were sharply divided over the composition of this body. The Union of Regeneration proposed a balanced slate of candidates; the Socialist Revolutionaries on the negotiating commission nominated three individuals-E. M. Timofeev, Zenzinov, and Avksent'ev-all of whom were members of the party's Central Committee. ${ }^{124}$ The Omsk delegation also proposed a slate comprised almost entirely of its own men (Vologodskii, Mikhailov, Sapozhnikov, and the Kadet S. V. Vostrotin in addition to General Alekseev), none of whom were socialists. ${ }^{125}$ The conference delegates eventually agreed to a compromise list of Avksent'ev, V. G. Boldyrev, N. I. Astrov, N. N. Chaikovskii, and Vologodskii. Argunov, General Alekseev, V. A. Vinogradov, Zenzinov, and Sapozhnikov were approved respectively as alternates, although the nonsocialist delegates were critical of the Socialist Revolutionary Zenzinov substituting for the Popular Socialist Chaikovskii; also, Vinogradov was considerably more liberal than Astrov.

The final compromise on the Constituent Assembly represented a clear defeat for the Socialist Revolutionaries. The party had upheld the Constituent Assembly as the voice of the people and therefore the sole source of legitimate political authority in Russia, and its opposition to the Bolsheviks was portrayed as the struggle to restore popular sovereignty. The terms set by the Ufa State Conference for the reconvening of the Constituent Assembly made recognition of it virtually meaningless. Approximately one hundred Constituent Assembly delegates were present in the Volga region at the opening of the conference; it was unlikely that another one hundred and fifty would arrive within the next three months, especially because the Bolsheviks were advancing on the front and stepping up repression of opposition parties. Moreover, the power that the Constituent Assembly would exercise even if convened was very uncertain; it was 
unlikely that the Directory would willingly surrender the unrestricted powers it would enjoy in the intervening months.

Part of the explanation for the defeat of the Socialist Revolutionaries lies within the party itself, divided as it was between those who argued for the necessity of compromise and coalition with the right, and those who insisted that the Bolsheviks could be defeated only by renouncing the principle of coalition and fighting alone under the banner of the Constituent Assembly and narodovlastie. Although the party leadership had shifted toward the latter position by the end of 1917, many within the party, including those in Siberia, were uncertain about exercising power without the right's cooperation, especially given the need for the financial and military backing of mostly conservative constituencies. It should be recognized, however, that the Socialist Revolutionaries' defeat at Ufa was as much the result of external pressures as internal fragmentation, for a compromise agreement became a matter of increasing urgency after the launching of a Red Army offensive in early September. As the conference proceeded, Komuch authority and prestige (and thus that of the Socialist Revolutionary Party) were severely undermined by reverses at the front, particularly the fall of Kazan on 10 September. This victory was quickly followed by Red Army offensives in Simbirsk, Syzran, and Samara provinces, the very heart of Komuch territory.

Like Komuch, the Provisional Siberian Government was compelled to accept the compromise agreement at Ufa. Until the final days of the conference, the Omsk delegation maintained an essentially inflexible position, having been instructed not to make any significant concessions even if this meant breaking off negotiations altogether. It abandoned this intransigence only in the final days of the conference, when the long-simmering conflict with the Regional Duma reached a boiling point. In an effort to assert its authority, the duma had sent delegations to both the Russian Far East and the Ufa State Conference; the delegates sent eastward were forcibly detained by representatives of the Provisional Siberian Government in Irkutsk, while those sent to Ufa were denied official participation with voting rights at the state conference. With most cabinet members away from 
Omsk, the Regional Duma saw a final opportunity to act. Shatilov and Krutovskii, who had left the government several weeks earlier, now returned to Omsk and demanded reinstatement in the cabinet. ${ }^{126}$ They were accompanied by I. A. Iakushev, the chairman of the duma, and the Socialist Revolutionary A. E. Novoselov, who had been appointed to the cabinet in late January but was only now arriving in Western Siberia. ${ }^{127}$ In response to the return of the leftist ministers, the Administrative Council, led by Mikhailov while Serebrennikov was at Ufa, ordered the suspension of the Regional Duma. Krutovskii, Shatilov, Novoselov, and Iakushev were arrested and forced at gunpoint to renounce all claims to their posts and to promise to leave the city. Krutovskii later explained that each of the ministers was threatened in turn and that he was told he had "three minutes to sign, or you'll be put in a car and shot." ${ }^{28}$ In the early hours of the following morning, Novoselov was killed on the outskirts of the city.

A. S. Stepanov, who commanded the unit responsible for the murder, later maintained that Mikhailov ordered both the arrests of the ministers and the killing of Novoselov. ${ }^{129}$ At the time, and in later inquiries, Mikhailov was at pains to assert that Colonel V. I. Volkov, the commander of the Omsk garrison, ordered the arrests without consulting either the cabinet or the commander-in-chief; Mikhailov further insisted that he was sick in bed the night of the arrests. At the same time, he admitted that he was concerned that tensions over Grishin-Almazov's recent resignation and the convening of the Regional Duma might complicate matters being decided at Ufa. ${ }^{130}$ Indications are strong that at least some members of the government were involved with Novoselov's murder: materials implicating him in the Bolshevik seizure of power in Omsk in 1917 clearly had been prepared beforehand, because they were presented to the district prosecutor the day after the murder. ${ }^{131}$ Moreover, in his testimony before the investigative commission, suggesting what might have been the thinking of the Administrative Council at the time, Serebrennikov remarked that admitting Novoselov to the cabinet would have set a dangerous precedent by encouraging other socialist members of the Derber group to return to Omsk. "This would have fundamentally altered the politics of 
the Siberian government and would have led to the dominance of the party element in the cabinet. " 132 The attempted assertion of authority made by the Regional Duma and the leftist ministers was unacceptable to the more conservative members of the government, regardless of whether they were motivated by a simple concern for power or by political principle. Differences between the right and the left, evident from the early months of the revolution, had come to be resolved by violence rather than debate.

Following the arrests in Omsk, Mikhailov ordered A. N. Gattenberger, the Tomsk provincial governor, "to take the most decisive measures as demanded by the situation. I will hold you responsible in case of delay or indecisiveness." On the evening of 23 September, the Tomsk militia broke up a meeting of the Regional Duma and arrested several delegates. ${ }^{133}$ Those delegates remaining at liberty met the following day, called for the cabinet to relocate to Tomsk, and demanded that Mikhailov, Gattenberger, and A. A. Gratsianov (the assistant minister of internal affairs) be dismissed from their posts and tried for their actions against the Regional Duma. They further asserted that in the meantime all authority was to be invested in a Duma Committee headed by Pavel Mikhailov, one of the former leaders of the West Siberian Commissariat. Gratsianov and Colonel Volkov were arrested by Czech troops acting on the orders of the Czechoslovak National Council's representative to the Regional Duma; the troops also had orders to arrest I. A. Mikhailov but could not find him. ${ }^{134}$ The duma delegates were detained for several days despite orders from the newly created Directory for their release; Gattenberger released them only on orders from the Administrative Council. ${ }^{135}$

The events of late September clearly signaled the political defeat of the Regional Duma; its attempt to reclaim authority in Siberia ended in dismal failure. Delegates meeting on 28 September voted in favor of recognizing the Directory even though they were critical of its call for the duma to exercise restraint in its dealings with the authorities in Omsk. On 2 October the duma reiterated its demand for the ouster and trial of I. A. Mikhailov and Gratsianov, as well as the reinstatement of the leftist ministers. ${ }^{136}$ The delegates also demanded that the 
Directory set a date within the coming two weeks for the reconvening of the Regional Duma. That none of these demands were met reveals the impotence of the duma. Golovachev later wrote of the events of late September that "with this conflict, the idea of democracy in Siberia perished." 137

The 2nd Siberian Congress of Socialist Revolutionaries, held in late September, gave a standing ovation in memory of Novoselov and demanded, without result, that the Regional Duma should oversee the investigation of his murder. ${ }^{138}$ The participants also asserted that only the Socialist Revolutionaries and the Social Democrats represented democracy in Russia and warned that "the revolution hasn't died yet but is in a seriously depressed condition. "139 They reluctantly offered their support to the Directory, explaining that "the refusal of democracy to participate in the government created on the principle of agreement would inflict a heavy blow to narodovlastie and would plunge a fragmented and disorganized country into a state of anarchy. ${ }^{140}$ Thus, the Socialist Revolutionaries in Siberia continued to insist on the need for coalition, despite increasingly obvious and irreconcilable differences with those to their right.

In a telegram to the Provisional Siberian Government in Omsk on 25 September, the Directory indicated its flexibility with regard to the Regional Duma; while respecting the duma's authority, the Directory proposed that "having in mind the impossibility of normal activity by the Regional Duma under the present circumstances, to postpone its activities until the creation of appropriate conditions." 141 The authorities in Omsk, however, were not satisfied with the Directory's conciliatory position, insisting that the duma should not be reconvened and that this was a matter to be resolved by the Provisional Siberian Government alone. The duma eventually assembled in Tomsk, with Avksent'ev in attendance, on 10 November, at which time all but one of the eighty-nine delegates present either voted in favor of dissolution or abstained. ${ }^{142}$ The defeat of the Regional Duma was complete.

The fate of the Directory represents the final blow to the democratic alternative in the east. Anxious about Ufa's proximity to the front, the Directory 
decided to relocate to Omsk soon after the close of the state conference, despite the opposition of the Socialist Revolutionaries. ${ }^{143}$ The new left-center majority among the party's Central Committee members in the east, led by V. M. Chernov, had argued against coalition since late 1917; now they feared that in moving to Omsk, the Directory would become a captive of the right. ${ }^{144}$ An internal party circular issued in late October, which came to be known as the Chernov Manifesto, expressed support for the Directory but went on to state that "the central focus of their tactics should be gathering together democratic forces and attaching them to the Constituent Assembly and its successor-the Congress of the Delegates to the Constituent Assembly." ${ }^{145}$ The circular also called for the creation of an independent armed force to protect the Constituent Assembly against potential reactionary threats. The concerns of the Socialist Revolutionaries soon proved well founded, as both the Directory and the remnants of the Constituent Assembly would fall victim to rightist forces.

In the weeks to follow, the members of the Directory, living and working in railroad cars on the outskirts of Omsk, engaged in tense and protracted negotiations with the Provisional Siberian Government over the composition of the new government. With control over the administrative apparatus and the army in Siberia, the Provisional Siberian Government had a commanding position in these talks, insisting on the closing of the Regional Duma, the retention of all previously enacted legislation, and final approval of all new ministerial appointments. These conditions were tantamount to the subordination of the Directory to the Provisional Siberian Government, a government which, like Komuch, was ostensibly subject to the Directory and slated for dissolution. I. A. Mikhailov's statement to the members of the Directory on 12 October reveals the real balance of power: "If they intend to dictate to the Siberian government, then there's no reason to gather here, for to dictate to the Siberian government is a completely hopeless matter. " 146 Just two weeks after declaring its authority over the non-Bolshevik territories in the East on 4 November, the Directory was overthrown in a military coup d'état backed by the army, trade-industrial circles, and the increasingly strident Siberian Kadets, 
with Admiral Kolchak becoming supreme commander; few on either the right or the left within the anti-Bolshevik opposition mourned its passing. With the overthrow of the Directory and the forcible dispersal of the remaining delegates to the Constituent Assembly, gathered in Ekaterinburg, which soon followed, the last chance for a democratic alternative to Bolshevik rule in the east had been lost, defeated in large part by divisions among the political forces that had supported such an alternative.

The opposition in Siberia at the time of the Kolchak coup was more fractured than it had been a year earlier. The Socialist Revolutionaries, who dominated the Regional Duma and led the initial military and political resistance to the Bolsheviks with the West Siberian Commissariat, were unable to maintain control over an increasingly conservative and assertive government. Remarking on tensions within the opposition, one Socialist Revolutionary stated that "all these various elements ... . parted ways, and most importantly, those elements who had not acted at all, but had built up enmity and thirst for revenge while sitting in a corner, now came forward. "147 The Provisional Siberian Government looked to the propertied elements and military circles for support, yet these groups were hostile toward any government that was even vaguely associated with the socialists, and they instead called with increasing insistence for the establishment of a dictatorship. The popular classes were either hostile toward the government, as were workers, or displayed little concern about politics, as did the peasantry. The Siberian case represents the fate of the democratic opposition to the Bolsheviks more generally, whereby the fragmentation and resulting impotence of the political center rendered the Russian Civil War a struggle between extremes of the right and the left. The Kolchak government, like the White regime in the south, conceived of the struggle with the Bolsheviks in military terms, thus ignoring or delaying the formulation of a political program that could effectively appeal to an increasingly alienated populace. Given the collapse of the center and the failings of the Whites, the Bolsheviks were assured of ultimate victory. 


\section{Notes}

1. A number of emigre memoirs and histories have recently been published in Russia, but historians are only now beginning to challenge earlier conceptualizations of the revolutionary period. Iu. A. Poliakov, in a section of Istoriia SSSR devoted to pedagogical questions, wrote that "in Soviet historiography there are practically no studies of the history of the White Guard camp . . . There is no doubt that serious work on the history of the social and political forces of the counterrevolution and an analysis of the structure and politics of the White Guard regimes and their military forces are needed in our discipline." "Grazhdanskaia voina v Rossii (poiski novogo videniia)," Istoriia SSSR no. 2 (1990): 101.

Some of the best known Western works on the civil war include: Oliver H. Radkey, The Sickle Under the Hammer: The Russian Socialist Revolutionaries in the Early Months of Soviet Rule (New York: Columbia University Press, 1963); Vladimir Brovkin, The Mensheviks After October: Socialist Opposition and the Rise of the Bolshevik Dictatorship (Ithaca, NY.: Cornell University Press, 1987); William Rosenberg, Liberals in the Russian Revolution (Princeton, NJ.: Princeton University Press, 1974). Brovkin, in Behind the Front Lines: Political Parties and Social Movements in Russia, 1918-1922 (Princeton, NJ: Princeton University Press, 1994), sets out to provide a comprehensive narrative of the civil war and argues for the viability of various political alternatives to Bolshevism, but he devotes only some dozen pages to 1918 .

There are still very few regional studies of the civil war. Recent notable exceptions include Norman G. O. Pereira's White Siberia: The Politics of Civil War (Montreal: McGill-Queen's University Press, 1996) and Jonathan D. Smele's Civil War in Siberia: The Anti-Bolshevik Government of Admiral Kolchak, 1918-1920 (Cambridge: Cambridge University Press, 1996). These works present new and valuable research on the civil war in Siberia, but both focus on the Kolchak regime and thus treat the period considered here only as an antecedent to White rule. Smele, moreover, made no use of Russian archives, and he cites only a limited number of materials held by the Hoover Institution Archive.

2. On Siberian Regionalism, see M. G. Sesiunina, G. N. Potanin i N. M. Ladrintsev: Ideologi sibirskogo oblastnichestva (Tomsk: Izdatel'stvo Tomskogo universiteta, 1974); I. A. Iakushev, Grigorii Nikolaevich Potanin: Ego zhizn' i deiatelnost' (Prague: Izdanie obshchestva Sibiriakov v ChSR, 1927); N. M. Iadrintsev, Sibir' kak koloniia (St. Petersburg: Tipografiia M. M. Stasiulevich, 1882). 
3. Pis'ma G. N. Potanina, 3 vols. (Irkutsk: Izdatel'stvo Irkutskogo universiteta, 1987), 2: 7.

4. Ibid., 1:24. In their correspondence, Potanin and Iadrintsev frequently discussed the socialist potential of the peasant obshchina, threatened by capitalist development in European Russia but seen as still potentially viable in Siberia. For example, see Potanin's June 10, 1874 letter to Iadrintsev, 2: 119-20.

5. E. I. Chemiak, Eserovskie organizatsii v Sibiri v 1917-nachale $1918 \mathrm{gg}$. (k istorii bankrotstva partii) (Tomsk: Izdatel'stvo Tomskogo universiteta, 1987), p. 55.

6. V. Vegman, "Oblastnicheskie illiuzii, rasseiannye revoliutsiei, "Sibirskie ogni, no. 3 (1923): 96. Vegman identifies five professors, fifteen professionals, six teachers, and thirteen employees of city, food, and cooperative organizations as among the delegates. In contrast, only seven workers and three peasants were represented. The assembly presidium was headed by B. D. Markov, a Socialist Revolutionary and privat-dotsent (instructor) at Tomsk University who later became one of the leaders of the West Siberian Commissariat. Paul Dotsenko, The Struggle for a Democracy in Siberia, 1917-1920 (Stanford, Cal.: Hoover Institution Press, 1983), p. 20.

7. Estimates of the number of delegates at this congress range from 169 to 200 . Kak voznikla Vremennaia Oblastnaia Sibirskaia Duma i Vremennoe Pravitel'stvo Avtonomnoi Sibiri (Informatsionnyi otdel Vremennago Pravitel'stva Avtonomnoi Sibiri, 1918), pp. 2-3. Eighty-seven of the delegates were Socialist Revolutionaries and their allies, while another twenty-five were Social Democrats. In contrast, only four Kadets and a handful of Regionalists were among the delegates. V. Maksakov and A. Turunov, Khronika grazhdanskoi voiny v Sibiri (1917-1918) (Moscow-Leningrad: Gosizdat, 1926), pp. 119-20.

8. Pervyi sibirskii oblastnyi $s^{\prime \prime e z d: ~ p o s t a n o v l e n i i a ~ s " e z d a ~(T o m s k: ~ G u b e r n s k a i a ~}$ tipografiia, 1917), pp. 1-3.

9. Ibid., p. 8.

10. I. I. Serebrennikov, Moi vospominanii (Tientsin: Star Press, 1937), p. 74.

11. Kak voznikla, p. 6. 
12. E. I. Cherniak, Politicheskie partii v Sibir' (mart 1917-noiabr' 1918 gg.): S"ezdy, konferentsii, soveshchaniia) (Tomsk: Tomskii gosudarstvennyi universitet, 1993), p. 17.

13. G. K. Guins, in Sibir', soiuzniki i Kolchak (Peking: Izdatel'stvo obshchestva vozrozhdeniia Rossii v Kharbine, 1921), p. 71, states that almost half the delegates were Soviet representatives, while Maksakov and Turunov, Khronika grazhdanskoi voiny, p. 121, maintain that only 34 of the 155 delegates came from the Soviets. This disagreement may well reflect the respective authors' political sentiments, with Guins challenging the extraordinary congress's legitimacy by tarring it with the brush of Bolshevism, while Maksakov and Turunov emphasize the distance between Soviet power and the opponents of the Bolshevik regime. The latter also provide the following information on other organizations represented at the Extraordinary Regional Congress: 10 delegates from the zemstvos, 21 from city dumas, and 26 from the cooperatives.

14. I. A. Iakushev, "Ocherki oblastnogo dvizheniia v Sibiri," Vol'naia Sibir', no. 3 (1928): 11 .

15. Cherniak, Eserovskie organizatsii, p. 151.

16. S. P. Mel'gunov, Tragediia Admirala Kolchaka (Belgrade: Russkaia tipografiia, 1930), p. 64. Most sources maintain that this effort was unsuccessful, although I. A. Iakushev, later chairman of the Regional Duma, claims that Krakovetskii raised fifty thousand troops but was unable to return to Siberia with them because of the overthrow of the Rada government and the subsequent establishment of Bolshevik rule in Ukraine. As commander of the Irkutsk garrison, Krakovetskii led the December 1917 revolt against the establishment of Bolshevik rule in the city. A Socialist Revolutionary and Regionalist, Krakovetskii served as a witness for the prosecution at the trial of the Socialist Revolutionaries in 1922.

17. Vegman, "Oblastnicheskie illiuzii," p. 111

18. Smele, Civil War in Siberia, p. 18.

19. M. A. Gudoshnikov, Ocherki po istorii grazhdanskoi voiny v Sibiri (Irkutsk: Irkutskoe knizhnoe izdatel'stvo, 1959), p. 69. Given the hurried circumstances of the convening of the Regional Duma, delegates were chosen by organizations rather than elected in a general vote.

20. "Pamiatnaia data," Vol'naia Sibir', no. 3 (1928): 5. 
21. Kak voznikla, p. 9.

22. S. G. Livshits, "Krakh 'Vremennogo pravitel'stva avtonomnoi Sibiri,"' Voprosy istorii, no. 8 (1974): 88.

23. "Declaration of the Siberian Regional Duma," G. K. Guins Papers (marginalia), Hoover Institution Archive.

24. Stephan M. Berk, "The Coup d'Etat of Admiral Kolchak: The Counterrevolution in Siberia and East Russia, 1917-1918," Ph.D. diss., Columbia University, 1971, pp. 77, 94. Lenin referred to Siberia as the "least Bolshevik" of regions in Russia. The Bolsheviks took only 10 percent of the Siberian vote in elections to the Constituent Assembly; the Socialist Revolutionaries won a dominating 75 percent. See V. T. Agalakov, Sovety Sibiri (1917-1918 gg.) (Novosibirsk: Nauka sibirskoe otdelenie, 1978), pp. 80, 85.

25. "Pamiatnaia data," pp. 3-8 and Dotsenko, Struggle for a Democracy, p. 22.

26. Iakushev, "Ocherki," p. 25.

27. Guins, Sibir', p. 77. The delegates chose fourteen ministers and another four ministers without portfolio, in addition to a state secretary and controller. Derber, prime minister of the government, was also named minister of agriculture. The other appointments were as follows: P. V. Vologodskii, minister of foreign affairs and assistant prime minister; I. I. Serebrennikov, minister of supplies; I. A. Mikhailov, minister of finance; G. B. Patushinskii, minister of justice; V. M. Krutovskii, minister of health; Tiber-Petrov, indigenous affairs; A. A. Krakovetskii, military; A. E. Novoselov, internal affairs; L. A. Ustrugov, transport; I. S. Iudin, labor; Kolobov, trade and industry; Rinchino, education; D. G. Sulim, extraterritorial affairs. M. B. Shatilov, V. A. Kudriavtsev, E. V. Zakharov, and Neometullov were named ministers without portfolio. V. I. Moravskii was state secretary, and N. E. Zhernakov was state controller.

28. By March, up to thirty members of the Regional Duma had followed the Derber group to the safety of Harbin. M. P. Golovachev, "Soveshchanie chlenov Sib. Obl. Dumy v Kharbine 1918 goda," Golovachev Papers, box 4, folder 1, Bakhmeteff Archive, Columbia University.

29. Rapid turnover in personnel shows the Derber group's weakness. By the end of July, just weeks after declaring its authority in Vladivostok, several ministers resigned, 
including Zakharov, Kudriavtsev, Neometullov, and Tiber-Petrov. Sources on the Provisional Government of Autonomous Siberia include: "Vremennoe Pravitel'stvo Avtonomnoi Sibir," Krasnyi arkhiv, no. 4 (29) (1928) Kak voznikla, Livshits, "Krakh 'Vremennogo Pravitel' stva', " Vestnik Vremennogo Pravitel'stva Avtonomnoi Sibiri (The Herald of the Provisional Government of Autonomous Siberia).

30. The cooperatives had become an important economic and institutional force in Siberia during World War I, attaining a membership of 1.7 million by 1917. See K. V. Gusev, Partiia Eserov (Moscow: Mysl', 1975), p. 230; A. N. Reznichenko, "Nachalo grazhdanskoi voiny v Sibiri: Bor'ba bol'shevikov protiv men'shevistsko-eserovskoi burzhuaznoi diktatury 1918 goda," in L. A. Vishakova, ed. Boevye gody, (Novosibirsk: Novosibirskoe knizhnoe izdatel'stvo, 1959), p. 41. The cooperatives also provided financial support to the Czech Legion and served as early intermediaries between the Legion and the military units led by the West Siberian Commissariat. See P. Lisovskii, Na sluzhbe kapitala: Esero-men'shevistskaia kontrrevoliutsiia (Leningrad: Priboi, 1928), p. 54; Maksakov and Turunov, Khronika, p. 149; "Coup d'Etat," pp. 157-58.

31. General Denikin, who met Grishin-Almazov in late 1918 after the latter joined the Volunteer Army, provides the following description: "Young, energetic, self-assured, somewhat arrogant, a liberal-perhaps more of a politician than a soldier, with great ambition and a touch of adventurism." A. I. Denikin, Ocherki russkoi smuty (Berlin: Knigoizdatel'stvo Slovo, 1924), vol.3: 102. Grishin-Almazov became commander of the forces in the Odessa region; surrounded by Bolshevik forces while crossing the Caspian Sea as an emissary to Kolchak, he threw his documents overboard and shot himself in the head (ibid., pp. 163-64).

32. Dotsenko, Struggle for a Democracy, p. 36. A 25 June decree of the West Siberian Commissariat referred to army volunteers' "sincere readiness to faithfully serve the idea of narodovlastie." Gosudarstvennyi arkhiv Rossiiskoi Federatsii (GARF), f. 151 (Zapadno-sibirskii komissariat), op. 1, d. 37, 1. 2.

33. D. S. "Proshloe i nastoiashchee," Vestnik obshchestva russkikh veteranov velikoi voiny, no. 52-53 (September-October 1930) Elena Varneck Papers, box 4, Hoover Institution Archive.

34. Mel'gunov, Tragediia Admirala Kolchaka, p. 68.

35. "Otchet o komandirovke iz Dobrovol'cheskoi Armii v Sibir' v 1918 godu, " Arkhiv 
russkoi revoliutsii, no. 9 (1923): 271

36. Ibid., p. 252.

37. Jules Chopin, Soiuznicheskaia interventsiia na Dal'nem Vostoke i v Sibiri: doklad Pishona (Moscow-Leningrad: Gosizdat, 1925), p. 48.

38. E. Agapov, "Sibirskaia nelegal'naia organizatsiia," V. I. Moravskii Papers, box 10, folder 45, Hoover Institution Archive.

39. The decision to revolt, which ran counter to orders from both the Czechoslovak National Council in Russia and the French military command, was made by a congress of legion delegates gathered in Cheliabinsk. A representative of the Czechoslovak National Council in Moscow dispatched a telegram to all railroad stations on 29 May, vainly urging that "Once more in the name of Professor Masaryk I call upon you to immediately cease all demonstrations and observe complete calm." GARF, f. 151, op. 1, d. 7,1 . 12. The legion played a central role in the civil war in the east until the Kolchak coup, when it adopted an essentially defensive posture. Studies of the legion's role in Russia include Edward Beneš, Souvenirs de guerre et de révolution (Paris: Librairie Ernest Leroux, 1928); J. F. N. Bradley, Le Légion Tchecoslovaque en Russie, 1914-1920 (Paris: Centre National de la Recherche Scientifique, 1965); Betty Miller Unterberger, The United States, Revolutionary Russia, and the rise of Czechoslovakia (Chapel Hill: University of North Carolina Press, 1989); Jindrich Vesely, Chekhi $i$ slovaki $v$ revoliutsionnoi Rossii (Moscow: Voennoe izdatel'stvo ministerstva oborony, 1965).

40. GARF, f. 151 , op. 1 , d. $37,1.13$.

41. Markov, Mikhailov, and Sidorov continued to be active in the Socialist Revolutionary Party and the opposition movement after the West Siberian Commissariat dissolved itself in late June. Markov and Mikhailov, who became involved in the Political Center underground directed against the Kolchak regime, were arrested in December 1919 and murdered the following month in Irkutsk, just prior to the fall of the city. Sidorov chaired the All-Siberian Union of Zemstvos and Municipal Authorities (Sibzemgor) during the Kolchak period and was named minister of interior for the shortlived Political Center government.

42. Dotsenko, Struggle for a Democracy, p. 37. 
43. GARF, f. 1805 (E. E. Kosolov, Lichnyi fond), op. 1, d. 4, 11. 1-2.

44. GARF, f. 151, op. 1, d. 37, 1. 12; ibid., d. 2, 1.2 .

45. Sobranie postanovlenii $i$ rasporiazhenii Zapadno-Sibirskogo Komissariata Sibirskogo Vremennogo Pravitel'stva, 28 June 1918, p. 5. Russia, Posol'stvo (France), box 27, Hoover Institution Archive. In the interim, all property that had been controlled by the Sovnarkhoz was to be placed under the control of the People's Industrial Committee (Narodno-promyshlennyi komitet). GARF, f. 151, op. 1, d. 6, 1. 177.

46. Sobranie postanovlenii, 30 June 1918, p. 4.

47. Ibid., 28 June 1918, p. 8.

48. GARF, f. 151, op. 1, d. 10, 1. 15. At the same time, however, Grishin-Almazov and Guins issued instructions that Bolsheviks were to be treated as prisoners of war rather than political opponents. Ibid., d. 6, 11. 229, 247.

49. Ibid., op. 1, d. 7, 1. 153.

50. Ibid., 11. 168-77.

51. Vologodskii was a Progressist member of the Second Duma and headed the Tomsk zemskaia uprava (provincial administration) in 1917. He served as prime minister in the Kolchak government until his resignation in August 1919. He died in Harbin in 1925. Guins, Sibir', p. 105; G. Z. Ioffe, Kolchakovskaia avantiura i ee krakh (Moscow: Nauka, 1983), p. 68.

52. Diary, 29 June 1918, P. V. Vologodskii Papers, Hoover Institution Archive.

53. Guins, Sibir', p. 111. S. A. Elachich, the editor of the conservative Samara newspaper Volzhskii den, ' provides the following assessment of Mikhailov, whom many referred to as Ivan Intriganovich (rather than Adrianovich): "But what was most important about Mikhailov wasn't his mind, much less his knowledge, but his immeasurable wiliness, as if it penetrated him thoroughly and marked all his actions." "Obryvki vospominanii, " p. 88, Elachich Papers, Hoover Institution Archive.

54. A. S. Soloveichik, Bor'ba za vozrozhdenie Rossii na Vostoke (Rostov: 1919), p. 23. Born in 1890 in a Siberian camp to which his father, a member of the People's Will, had 
been exiled, Mikhailov studied financial law at St. Petersburg University and in 1917 worked under A. I. Shingarev at the Ministry of Agriculture. After the October Revolution, he returned to Siberia as an employee of the cooperatives. Mikhailov played an equally central and nefarious role in the Kolchak government until he was forced to resign in August 1919. He later found employment with the Japanese Military Mission in Harbin and was involved with the All-Russian Fascist Party. In August 1946, Mikhailov was tried with Ataman Semenov and six others by the Military Collegium led by Ulrikh. He was shot in the cellars of the Lubyanka on 30 August. For more details on Mikhailov's activities in emigration and his ultimate fate, see John Stephan, The Russian Fascists (New York: Harper \& Row, 1978).

55. Serebrennikov, Moi vospominanii, p. 129; Vologodskii, Diary, 7 June 1918. Born in 1873 in Kansk District, Patushinskii attended Moscow University before returning to Siberia. He ran for the Constituent Assembly as a Popular Socialist and later served as minister of justice in the short lived Political Center government created in Irkutsk following the collapse of the Kolchak regime. Finally, he was a member of the defense team in the 1922 trial of the Socialist Revolutionaries.

56. Guins, Sibir', p. 106. The sixty-three-year-old Krutovskii was from a peasant family that moved to Siberia while he was still a child. An 1881 graduate of the St. Petersburg Medical-Surgical Academy, Krutovskii was a Regionalist and became editor of Sibirskie zapiski in 1916.

57. E. I. Cherniak, "Esery Sibiri i vopros o vlasti (mart-iul' 1917 g.)," in I. M. Razgon, S. F. Fominykh, E. I. Cherniak, eds., Klassy $i$ partii $v$ Sibiri nakanune $i v$ period velikoi oktiabr'skoi sotsialisticheskoi revoliutsii (Tomsk: Izdatel'stvo Tomskogo universiteta, 1977), p. 99. Shatilov was of peasant origins and graduated from Tomsk University in 1909. A Socialist Revolutionary, he was also involved in Regionalist activities in 1917.

58. Sobranie postanovlenii, 5 July 1918, pp. 1-2, 7.

59. GARF, f. 151, op. 1, d. 1, 1. 19.

60. Sobranie postanovlenii, 5 July, p. 7, and 26 July, p. 5, 15 July, pp. 17-18. Posol'stvo (France) box 27. Hoover Institution Archive.

61. Congress Resolution, pp. 2-3, Vologodskii Papers, Hoover Institution Archive. 
62. G. B. Patushinskii, Rech' ministra iustitsii G. B. Patushinskago (Omsk: Tipografiia Akmolinskogo oblastnogo pravleniia, 1918).

63. Congress Resolutions, p. 6.

64. Industrial Section of the 1st Siberian Trade-Industrial Congress, pp. 3-4, Vologodskii Papers.

65. Resolution of Organizational Section of the Congress, p. 7, Vologodskii Papers.

66. Cherniak, Eserovskie organizatsii, pp. 20-22; O. A. Kharus, "K voprosu o politicheskoi organizovannosti sibirskoi burzhuazii nakanune sotsialisticheskoi revoliutsii," in M. E. Plotnikova, E. I. Cherniak, E. N. Kosykh, eds., Oktiabr' $i$ grazhdanskaia voina v Sibiri: istoriia, istoriografiia, istochnikovedenie (Tomsk: Tomskii gosudarstvennyi universitet, 1993), p. 24.

67. Quoted in A. N. Reznichenko, Bor'ba bol'shevikov protiv "demokraticheskoi" kontrrevoliutsii v Sibiri $1918 \mathrm{~g}$. (Novosibirsk: Zapadno-Sibirskoe knizhnoe izdatel'stvo, 1972), p. 91. The All-Siberian Kadet Conference held in August supported the establishment of a one-man dictatorship. Maksakov and Turunov, Khronika grazhdanskoi voiny, p. 83.

68. Maksakov and Turunov, Khronika grazhdanskoi voiny, pp. 207-08.

69. Cherniak, Politicheskie partii, pp. 168-69.

70. A. I. Stepanov, manuscript, Hoover Institution Archive. By August, the Siberian army included three corps of 40,000 Cossacks and 10,000 officers. N. N. Golovin, Rossiiskaia kontrrevoliutsiia v 1917-1918 g.g. (Paris: Illiustrirovannaia Rossiia, 1937), pp. 4, 15. The mobilization decree issued in early August for those born in 1898 and 1899 eventually produced a force of 200,000 men.

71. Letter to the Secretary of State, 29 September 1918, Ernest Lloyd Harris Papers, box 5, Hoover Institution Archive.

72. Guins, Sibir', p. 195.

73. Vologodskii, Diary, 4 September 1918. 
74. The relationship between Mikhailov and Grishin-Almazov is obscure, particularly as in his $\mathbf{3 0}$ July diary entry Vologodskii writes that Mikhailov warned him that GrishinAlmazov was planning a coup; Vologodskii dismissed the warning as a reflection of the fact that Mikhailov was exhausted and overworked. It was rumored that GrishinAlmazov's wife, a chanteuse from Khabarovsk with a fondness for décolleté silk dresses and liquor and the hostess of the conservative salon in Omsk, was romantically involved with Mikhailov. See I. S. Il'in, "Omsk. Direktoriia. Kolchak," Novyi zhurnal, no. 72 (1963): 206.

75. Guins, Sibir', p. 197. Ivanov-Rinov had served with the tsarist police in Turkestan prior to the revolution. Several writers describe his abuses while serving as military governor in Vladivostok under Kolchak. He fled to China with the collapse of the Kolchak regime and was associated there with Ataman Semenov. Eventually, he returned to the Soviet Union and entered the ranks of the Red Army. His later fate is unknown.

76. Dotsenko, Struggle for a Democracy, p. 43.

77. GARF, f. 151, op. 1, d. 4, 11. 110-11.

78. Ibid., 11. 17-19.

79. V. A. Kadeikin, Rabochie Sibiri v bor'be za vlast' sovetov (Kemerovo: Kemerovskoe knizhnoe izdatel'stvo, 1966), p. 128.

80. Agalakov, Sovety Sibiri, pp. 124, 152.

81. Cited by M. Kordonskaia, "Sibirskoe krest'ianstvo v dni Oktiabr'skoi Revoliutsii," Proletarskaia revoliutsiia, no. 9 (1928): 2.

82. Reznichenko, Bor'ba bol'shevikov, p. 91.

83. For example, see D. K Shelestov, "O nachale povorota sibirskogo trudovogo krest'ianstva storonu sovetskoi vlasti," Istoriia SSSR, no. 1 (1962): 122.

84. Ibid., pp. 130, 139.

85. Guins, Sibir', p. 122.

86. Berk, "Coup d'Etat", p. 250. 
87. M. A. Krol', "Sibirskoe Pravitel'stvo i avgustovskaia sessiia Sibirskoi Oblastnoi Dumy," Vol'naia Sibir', no. 4 (1928): 76-78.

88. It was rumored that the army was planning to arrest the delegates to the Regional Duma and that only the intervention of the Czech Legion blocked these plans. ibid., p. 78.

89. Ioffe, Kolchakovskaia avantiura, p. 72.

90. The lowest figure is given by Maksakov and Turunov in Khronika grazhdanskoi voiny, p. 203 and the highest by M. V. Shilovskii in "Sibirskoe oblastnichestvo i kontrrevoliutsiia: $k$ probleme vzaimnootnosheniia, " in I. Korablev and V. I. Shishkin, eds., Iz istorii interventsii $i$ grazhdanskoi voiny $v$ Sibirii na Dal'nem Vostoke (Novosibirsk: Nauka, 1985), p. 171.

91. Mel'gunov, Tragediia Admirala Kolchaka, p. 163.

92. Krol', "Sibirskoe Pravitel'stvo," pp. 73-74.

93. GARF, f. 1805, op. 1, d. 5, 11. 1, 6-7.

94. Golovin, Rossiiskaia kontrrevoliutsiia, pt. 4, p. 22.

95. GARF, f. 151 , op. 1 , d. 4,1 . 2. The draft for this speech is found in Guins's papers at the Hoover Institution Archive.

96. Ibid., 1. 11.

97. Vologodskii, Diary, 14 August 1918.

98. Golovin, Rossiiskaia kontrrevoliutsiia, pp. 30-31.

99. Zaria, 18 September 1918, in P. Ostroukhov Papers, Newspaper articles, 1918-1920, (Harbin), Hoover Institution Archive.

100. GARF, f, 131, (Administrativnyi Sovet Vremennogo Sibirskogo Pravitel'stva), op. 1 , d. 103, 1.7 . 
101. Disagreements over the question of coalition emerged as early as the 3rd Party Congress in May 1917, when delegates approved participation in the Provisional Government but added that such a coalition was appropriate only for some undefined transitional period. See Oliver Radkey, The Agrarian Foes of Bolshevism (New York: Columbia University Press, 1958), pp. 209-12. Attempts to paper over party divisions on the issue of coalition were unsuccessful and after the failure of the Kornilov revolt led to an open rift, with Chernov and the party's left-center asserting that the time had come for the establishment of an all-socialist government, while the right argued for continued cooperation with the Kadets. The left-center won a tenuous majority at the 4th Party Congress in November, but during the civil war many party members continued to favor the coalition of parties opposed to the Bolsheviks.

102. These decrees may be found in Prikazy komiteta chlenov Uchreditel'nogo Sobraniia, (Samara: Tipografiia M. Feigel'man, 1918).

103. P.D. Klimushkin, "Volzhskii front Uchreditel'nogo Sobraniia v 1918 g.," Grazhdanskaia voina na Volge (Prague: Izdanie uchastnikov volzhskogo dvizheniia, 1930), p. 61.

104. Krol' was a member of the Kadet Party's Central Committee and a Constituent Assembly delegate from Ekaterinburg. A member of the Urals Regional Government, Krol' continued to be politically active in Siberia under the Kolchak regime and in the Far Eastern Republic. He ended up running a rather unsuccessful taxi service in Paris, where he died in 1941. His memoirs, Za tri goda (Vladivostok: "Svobodnaia Rossiia," 1921), are invaluable for historians of the civil war in the East.

Convinced advocates of coalition, Pavlov and Argunov were critical of the Socialist Revolutionary-dominated Komuch government. Argunov, the editor of Volia naroda in 1917, states: "I not only refused to take any part in the affairs of Komuch, but also took issue with its legality." "Omskie dni v 1918 godu," Sibirskii arkhiv, no. 5 (1935): 191. Pavlov was among those Socialist Revolutionaries who later voted against the Central Committee's call to oppose the Kolchak regime. K. S. Burevoi, Raspad (Moscow: Novaia Moskva, 192?), p. 36.

105. Avksent'ev, the leader of the Socialist Revolutionary Party's right wing, served as minister of interior under Kerensky and chaired the Democratic Conference. V. L. Utgof, a member of the Komuch government, described Avksent'ev as a "great master of compromise decisions and the securing of paper guarantees." "Ufimskoe gosudarstvennoe soveshchanie 1918 goda, "Byloe, no. 16 (1921): 24. A devoted party man, Zenzinov is described by Radkey as the "keeper of the party's conscience." Chernov provides a less 
flattering assessment of Zenzinov, stating that he was "a typical party bureaucrat, a chinovnik of the revolution. "Radkey, Agrarian Foes, p. 415; V. M. Chernov, "TsK PSR na rubezhe dvukh revoliutsii," p. 6, Chernov Papers, Hoover Institution Archive. Both men were expelled from Russia in the immediate wake of the Kolchak coup and were active in emigre politics. Avksent'ev died in Paris in 1943; Zenzinov, who resided in Paris, Prague, and Berlin before settling in New York, died in 1953.

106. A. A. Argunov, Mezhdu dvumia bol'shevizmami (Paris: Union, 1919), p. 12.

107. Golovin, Rossiiskaia kontrrevoliutsiia, pt. 4, p. 60.

108. S. N. Nikolaev, "Politika 'Komucha' (opyt kharakteristiki)" in Grazhdanskaia voina na Volge, p. 154.

109. GARF, f. 670 (Sovet upravleniia Komucha), op. 1, d. 1, 1. 9. Gendel'man was arrested along with Avksent'ev and Zenzinov at the time of the Kolchak coup. In 1920 he was arrested by the Bolsheviks and was among the defendants in the 1922 trial of the Socialist Revolutionaries.

110. GARF, f. 144 , op. 1 , d. $27,11.13-22$.

111. A former teacher from Biisk, Pepeliaev served in the 4th Duma and became a member of the Kadet Party's Central Committee in 1917. Like his brother Anatolii, who was a leading figure in the Siberian military underground, Pepeliaev was virulently antisocialist. He succeeded Vologodskii as prime minister of the Kolchak government and was executed alongside Kolchak in February 1920.

112. "Otchet o komandirovke," p. 292.

113. "Ufimskoe gosudarstvennoe soveshchanie," Russkii istoricheskii arkhiv, no. 1 (1929): 65. These are the stenographic records given to conference delegates, later deposited in the Prague Archive and subsequently published.

114. GARF, f. 144 , op. 1, d: 4 , 11. 31-34.

115. S. P. Rudnev, Pri vechernykh ogniakh (Kharbin: Zaria, 1928), pp. 246-47.

116. Guins, Sibir', p. 229; Mel'gunov, Tragediia Admirala Kolchaka, p. 182; M. I. Svetachev, Imperialisticheskaia interventsiia v Sibiri i na Dal'nem Vostoke (1918-1922 
gg.) (Novosibirsk: Nauka, 1983), pp. 91-93.

117. Maksakov and Turunov, Khronika grazhdanskoi voiny, p. 232. Serebrennikov admits that he was in daily contact with both Mikhailov and Vologodskii during the conference, but maintains that these contacts were solely informational and "weren't strong directives to which I had to quickly and unconditionally submit." I. I. Serebrennikov, "K istorii Sibirskogo pravitel'stva, " p. 7, Srebrennikov Papers, box 9, Hoover Institution Archive.

Serebrennikov, the minister of supplies, had been a radical activist in 1905, but later became a rather moderate Regionalist. He served briefly in the Kolchak government before the Ministry of Supplies was dismantled in December 1918. After the civil war he taught at the law school in Harbin. His papers are a valuable resource on events in Siberia.

118. The Paris delegation of Social Revolutionaries to the Party Central Committee in Moscow, Boris Nicolaevsky Collection, series 7, box 8, folder 27, Hoover Institution Archive.

119. "Ufimskoe gosudarstvennoe soveshchanie," p. 67. Along with Chernov, Vol'skii was one of the founders of the Socialist Revolutionary Party. He and a few other Socialist Revolutionaries agreed to negotiations with the Bolsheviks upon the latter's capture of Ufa. The so-called Ufa Group of Vol'skii, Burevoi, Rakitnikov, and Sviatitskii, was castigated by the mainstream Socialist Revolutionaries, and they formally broke with the party in the fall of 1919. Renamed the Narod Group after its journal of the same name, Vol'skii and his associates called for cooperation with the Soviet government and the Red Army in the struggle against the forces of reaction. The membership of this group never exceeded one thousand, and they were subject to Cheka persecution by 1920 . For more details on this group see M. N. Petrov, "Vozniknovenie i raspad men'shinstva partii Eserov, " Voprosy istorii, no. 7 (1979): 49-60. Vol'skii was arrested in 1922, but did not testify at the trial of the Socialist Revolutionaries. He died in exile in 1937.

120. Ibid., p. 122. He further stated that "the government must be hard, powerful, strong, possessing a single will, and above all directed toward the reestablishment of a Great Russia and renewal with the allies of the war with the Austro-German coalition." GARF, f. R-127, (Ia. S. Dvorzhets, Lichnyi fond), op. 1, d. 2, 1. 15. A professor of botany and later rector of Tomsk University, Sapozhnikov was a Regionalist who served as minister of education in the Provisional Siberian Government. He withdrew from politics after the Kolchak coup, and died in Tomsk in 1924. 
121. The antipathies generated by the land issue are reflected in L. A. Krol's rejection of the Constituent Assembly's land decree of 5 January 1918, when he stated that "if the point is not correspondingly altered, then not a single Kadet will be in a position to enter the Government." No reference was made to the decree in the final compromise agreement at Ufa. "Ufimskoe gosudarstvennoe soveshchanie," pp. 204, 212.

122. Quoted by L. A. Krol' in Za tri goda, p. 109.

123. "Ufimskoe gosudarstvennoe soveshchanie," pp. 190, 227

124. A right-center member of the Central Committee, Timofeev, like Argunov and Pavlov, refused to join the Komuch government. He was arrested in 1920 and was sentenced to prison and exile following the 1922 trial of the Socialist Revolutionaries. He was executed in 1941.

125. The owner of a gold mine and the former mayor of Yeniseisk, Vostrotin had served as a delegate to the 3rd and 4th Dumas. He joined Khorvat's cabinet in the spring of 1918.

126. In his later deposition to the investigative commission, Krutovskii stated that when he met Vologodskii in Krasnoyarsk in mid-September, he was urged to return to Omsk as "the situation that has been created is very serious." GARF, f. 189 (Chrezvychainaia sledstvennaia komissiia, uchrezhdennaia Administrativnym Sovetom Vremennogo Sibirskogo Pravitel'stvo), op. 1, d. 8, 1. 3. Iakushev similarly testified about Vologodskii's support for their actions, and stated that he was further motivated to go to Omsk out of concern for the government's position at Ufa and the turning back of the Regional Duma's delegation to the Russian Far East. ibid., d. 1, 11. 83-84.

127. Vologodskii, who met with him in Irkutsk on 12 September, believed that Novoselov intended to pursue publicistic work and had no plans to claim his post in the government. Vologodskii, Diary, 12 September 1918. Guins, who accompanied Vologodskii, asserts that Novoselov said he would participate in the work of the Regional Duma. Guins, Sibir', p. 214. Shatilov claimed that he had persuaded Novoselov to take up his cabinet post. GARF, f. 189, op. 1, d. 1, 11. 74-75.

128. GARF, f. 189 , op. 1, d. 8, 1. 11 .

129. Stepanov, Outline for memoirs. Stepanov's claims are supported by the fact that arrangements were quickly made for his "escape" from prison and relocation far from 
Omsk. By the time an arrest order was issued on 26 September, Stepanov was nowhere to be found.

Ensign Semenchenko, one of the shooters, claimed that Novoselov was killed trying to escape, and that he refused to stop when ordered to do so. Novoselov was shot three times in the head, making it unlikely that he was killed while attempting to flee. GARF, f. 189, op. 1, d. 1, 11. 3-6. The men responsible for the murder claimed to be acting on the orders of Colonel Volkov. Volkov was not the savviest of individuals; at one point in his deposition he argued that as a fighting officer he had no interest in political matters, but then he added that "I am not a politician, but I am interested in it. " Volkov's political perspective was unique, as he mused that "If we are going to arrest one another, one could make peace with that, but if the Czechs, our former allies, were to arrest our ministers, that would be a disgrace, a slap in the face to our pride." ibid., d. 2, 11. 40-48.

130. GARF, f. 131, op. 1, d. 103, 1. 24.

131. GARF, f. 189, op. 1, d. 2, 11. 32-33.

132. Ibid., 1. 63.

133. Ibid., 1. 94. Shatilov later testified that Mikhailov telegrammed Gattenberger soon after the Administrative Council's 8 September decree to inquire whether the garrison forces in Tomsk were adequate to carry out the suspension of the Regional Duma. This telegram provides at least indirect evidence of Mikhailov's intentions. Delegates to the Regional Duma intercepted the telegram, heightening suspicions and animosity toward the authorities in Omsk prior to the events here described. ibid., d. 1, 11. 69-70.

134. Golovin, Rossiiskaia kontrrevoliutsiia, pt. 4, p. 41.

135. "Sibirskaia oblastnaia duma," Boris Nicolaevsky Collection, series 145 , box 213 , folder 1.

136. Krutovskii later stated that he refused the Regional Duma's request to resume his post, suggesting instead that the only solution to the present situation would be the selection of an entirely new cabinet. The Regional Duma attempted to force Krutovskii to return to Omsk, threatening him with criminal prosecution if he refused to comply. GARF, f. 189, op. 1, d. 8, 11. 16-17. 
137. M. P. Golovachev, "The Siberian Movement and Communism," p. 150, Golovachev Papers, box 1.

138. A commission to investigate the events of late September was first established by the Provisional Siberian Government on 23 September, with the Directory assuming control of the investigation a week later. The investigation, as continued by the Kolchak government, was turned into a political indictment of the left; Nauman, the head of the court, issued a separate opinion in which he castigated the Regional Duma and the Socialist Revolutionaries (he asserted that several party members, including Iakushev and Shatilov, should be brought up on criminal charges). GARF, f. 189, op. 1, d. 5, 11 . 160-65.

139. Ibid., d. 1, 11. 100-05.

140. Cherniak, Politicheskie partii, p. 172.

141. Maksakov and Turunov, Khronika grazhdanskoi voiny, p. 243.

142. V. Krutovskii, "Oblastnoe obozrenie," Sibirskie zapiski, no. 4 (1918): 92. A vote taken on 4 November was twenty-five to eighteen in favor of dissolution, with all the opposing votes coming from the Socialist Revolutionary delegates. The ever conciliatory Iakushev, in a conversation with Avksent'ev the following day, expressed his concern about securing agreement to dissolution of the Regional Duma. It is not clear how the disposition of forces changed so drastically in just a matter of days, although Iakushev remarked that "it is reminiscent of the attitude of our fraction at Ufa when, having begun from a position on the left, soon went over to another under the pressure of events." GARF, f. 180, (Upravlenie delami Vremennogo Vserossiiskogo Pravitel'stva), op. 2, d. 87, 11. 7-8, 13.

143. While the Komuch cabinet and the Socialist Revolutionary Central Committee members remained in Ufa, the remaining Constituent Assembly delegates relocated to Ekaterinburg after being warned against following the Directory to Omsk. Soon after the close of the Ufa State Conference, the number of delegates declined from one hundred to forty, reflecting a recognition of the defeat suffered at Ufa. N. V. Sviatitskii, $K$ istorii Uchreditel'nogo Sobraniia (Moscow: Narod, 1921), p. 72n.

144. V. M. Chernov, "Chernovskaia gramota' i Ufimskaia Direktoriia, " p. 17, Chernov Papers. 
145. Ibid., p. 3. The party circular was published in the Ufa newspaper Narodnoe delo as "To All Party Organizations."

146. GARF, f. 131, op. 1, d. 252, 1. 3. Avksent'ev, Zenzinov, and Vologodskii all threatened to resign during the negotiations. The major sources of disagreement were the appointments of Mikhailov, implicated in Novoselov's murder and despised by the left, and Rogovskii, a Socialist Revolutionary who had served as head of the Irkutsk militia under the Provisional Government. Mikhailov remained minister of finance, while Rogovskii was made assistant minister of internal affairs under Gattenberger (who, it will be recalled, was involved in the actions taken against the Regional Duma in September). On 31 October, in what was described as the Directory's "final formulation" regarding Mikhailov, it was stated that "At the given time, in the present political situation, the inclusion of I. A. Mikhailov in the Council of Ministers would be completely [crossed out] unsuitable and politically harmful." The Directory members added that this should not be seen as an ultimatum; given Mikhailov's retention in the cabinet, it clearly was not. GARF, f. 180, op. 1, d. 2, 1. 1.

147. N. I. Rakitnikov, Sibirskaia reaktsiia $i$ Kolchak (Moscow, Narod, 1920), p. 7. 